\title{
Impaired Renal Conservation of Sodium and Chloride during Sustained Correction of Systemic Acidosis in Patients with
} Type 1, Classic Renal Tubular Acidosis

\author{
Anthony Sebastian, Elisabeth McSherry, and R. Curtis Morris, Jr. \\ From the Departments of Medicine and Pediatrics, University of California, \\ San Francisco, California 94143
}

A B S T R A C T In 10 patients with classic renal tubular acidosis in whom correction of acidosis was sustained with orally administered potassium bicarbonate, renal conservation of sodium was evaluated when dietary intake of sodium was restricted to 9-13 meq/day. In five patients, renal conservation of sodium was impaired by at least one criterion of impairment. In the remaining patients, renal conservation of sodium appeared to be relatively well-maintained, but an impairment could not be excluded. In each of six patients studied during induced water diuresis, including two in whom renal conservation of sodium was not unequivocally impaired, the minimal urinary concentrations of sodium were inappropriately high and the urinary excretion rates of sodium were flow-dependent. These results provide direct evidence that an abnormality in renal transport of sodium can occur in classic renal tubular acidosis, and compel a reconsideration of the pathophysiology of disordered renal transport of sodium in this disorder. The results indicate that in at least some patients with classic renal tubular acidosis impaired renal conservation of sodium is not exclusively a reversible consequence of the renal acidification defect. These findings raise the question whether renal transport of sodium is unimpaired in any patients with classic renal tubular acidosis. In the presently studied patients, the impairment in renal conservation of sodium appeared to be in part the consequence of an impaired ability of the vasopressinresponsive segments of the distal nephron to generate and maintain appropriately steep transepithelial sodium concentration gradients.

Received for publication 14 November 1973 and in revised form 19 April 1976.

\section{INTRODUCTION}

In patients with classic renal tubular acidosis (type 1 , "distal" RTA), ${ }^{1}$ irrespective of the presence or absence of nephrocalcinosis, correction of systemic acidosis with alkali therapy can result in a reduction of the urinary excretion rate of potassium, sodium, and aldosterone (1-9) ; when correction of acidosis is sustained and dietary intake of sodium and potassium is not restricted, the external balance of potassium and sodium can become sufficiently positive to correct hypokalemia and secondary hyperaldosteronism $(4,5)$. It has been inferred from these observations that the impairment in renal conservation of potassium and sodium demonstrable in untreated, acidotic patients with classic RTA is fully corrected when acidosis is corrected with alkali therapy (5). This inference constitutes the basis for the widely accepted conclusion that in classic RTA impaired renal conservation of potassium and sodium is exclusively a reversible consequence of the renal acidification defect $(5,10-13)$. But the validity of this inference can be questioned, since it cannot be ascertained from the results of published studies whether renal conservation of potassium and sodium is unimpaired when dietary intake of these ions is restricted and correction of acidosis is sustained (1-9). In some patients with classic RTA, renal potassium wasting and hyperaldosteronism persist during sustained correction of acidosis with alkali therapy, despite provision of even supernormal amounts of dietary sodium (6). Hence, in at least some patients with classic RTA, impaired re-

${ }^{1}$ Abbreviation used in this paper: RTA, renal tubular acidosis. 
nal conservation of both sodium and potassium might persist during sustained correction of acidosis.

In the present investigation of children and adult patients with classic RTA, we have evaluated renal conservation of sodium when dietary intake of sodium was restricted and correction of systemic acidosis was sustained with potassium bicarbonate. Renal conservation of sodium and chloride was impaired in 5 of 10 patients studied and was not unequivocally unimpaired in the remaining patients. In the patients studied who had Sjogren's syndrome and/or hypergammaglobulinemia, the impairment in renal conservation of sodium might have been a consequence of the primary pathological process in the kidney (interstitial nephritis), which can result in multiple dysfunctions of the renal tubule (14-16); in these patients and in those with idiopathic RTA as well, the impairment might have been a consequence of secondary renal parenchymal damage associated with nephrocalcinosis and infection. But whatever its pathogenesis, the occurrence of impaired renal conservation of sodium in patients with classic RTA during sustained correction of acidosis compels the conclusion that the impairment is not exclusively a reversible consequence of the renal acidification defect. The results of the study render problematic the primacy of the renal acidification defect in the pathogenesis of impaired renal reabsorption of sodium and other inorganic ions in classic RTA.

\section{METHODS}

In seven adult patients and three children with classic RTA (Table I), renal conservation of sodium and/or chloride was evaluated during restriction of dietary intake of sodium and/or chloride. In some of these patients, results of studies of renal tubular function have been published $(6-8,20,21)$. In each patient, the dysfunction of renal acidification was characterized by a persistently inappropriately high urinary $\mathrm{pH}$ during acidosis; in most patients, urinary excretion of acid was inappropriately reduced during acidosis, and reabsorption of filtered bicarbonate was nearly complete $(>95 \%)$ at normal plasma bicarbonate concentrations sustained with orally administered alkali. None of the patients were azotemic and none had the complex dysfunction of the proximal renal tubule characteristic of the Fanconi syndrome. For months or years before the present studies, correction of systemic acidosis and hypokalemia had been sustained in each patient by administration of sodium bicarbonate, usually in combination with potassium bicarbonate.

Intake of sodium was restricted in each of the 10 patients. Throughout the period of restriction and for at least 1 wk before, each patient received a constant metabolic diet containing 9-13 meq of sodium/day, and each patient was maintained nonacidotic by oral administration of potassium bicarbonate $(60-120 \mathrm{meq} /$ day in the adult patients, 55-80 meq/day in the children). For a period of 3-5 days before initiating the period of sodium restriction, each adult patient was maintained in sodium balance with 85-120 meq of sodium chloride/day administered orally as a supplement; each child was maintained with a daily supplement of sodium chloride of $1.5-3.5 \mathrm{meq} / \mathrm{kg}$ of body weight. The period of sodium restriction was initiated by discontinuing the supplement of sodium chloride and was continued for 8-10 days.

When the supplement of sodium chloride was discontinued in two patients, $30-50 \mathrm{mmol}$ of potassium chloride was administered daily in substitution for an equal amount of potassium bicarbonate. Potassium chloride was substituted for potassium bicarbonate to prevent or to lessen an increase in plasma bicarbonate concentration that might have been expected to occur with sodium depletion and reduction of the extracellular fluid volume. Hence, in these patients, the intake of sodium but not chloride was restricted. A similar study was carried out in a single normal subject to investigate the possibility that renal conservation of sodium during restriction of sodium might be limited by continued intake of chloride.

Immediately before terminating the period of sodium restriction, the effect of changes in urine flow on urinary concentration and excretion rate of sodium was examined in six patients in whom water diuresis was induced by orally administered water, in amounts ranging from 15 to $25 \mathrm{ml} / \mathrm{kg}$ of body weight.

Study procedures and chemical analyses of blood and urine were carried out as described previously $(6,7,18$, 20,21 ).

In initial studies of renal conservation of sodium, the dietary content of sodium was estimated from food composition tables (22). 1-4 yr after the studies were completed, the patients' diets were reproduced and the content of sodium measured. Reproduction was exact with respect to the items of food and their weights. The content of sodium was measured in 17 diets from 11 studies of 10 patients, a total of 32 samples of homogenized diet were analyzed (Table II). At least one diet was analyzed for every study. In the initial study of one patient (C. V.), the original diet was prepared in duplicate, one duplicate was homogenized and frozen when the study was in progress; the content of sodium in this diet was measured and compared with that in the diet prepared $3 \mathrm{yr}$ later. In another patient (A. B.), the content of sodium was measured in a diet duplicated during the progress of a second study of sodium restriction. Thus, in two studies the content of sodium was determined in a duplicate of the ingested diet at the time the studies were carried out. In C. V. and A. B., the content of sodium was measured in diets duplicated on three or more occasions 1-4 yr apart.

Dietary analyses were carried out as follows: food and beverage for one 24-h period of the diet was weighed and homogenized. Duplicate samples of approximately $20 \mathrm{~g}$ each were weighed and mixed with $30 \mathrm{ml}$ of water and $5 \mathrm{ml}$ of concentrated nitric acid. The mixture was boiled for $15 \mathrm{~s}$, cooled, filtered into a $100-\mathrm{ml}$ volumetric flask through double-thickness Whatman no. 42 filter paper, and diluted to volume with water. A water blank and samples of standard solutions containing 10,20 , and $50 \mathrm{meq} / 1$ sodium chloride were treated in the same manner. Deionized water was used in all procedures. The concentration of sodium was determined by flame photometry (Instrumentation Laboratories' Flame Photometer model no. 343 with internal lithium standard. Instrumentation Laboratory, Inc., Lexington, Mass.). Specimens were diluted with lithium chloride solution so that the final concentrations of sodium ranged between 0 and $0.9 \mathrm{meq} / 1$ in $15.0 \mathrm{meq} / 1$ lithium chloride. Within this range of sodium concentrations, the standard curve was linear. 
TABLE I

Clinical and Physiologic Data in Patients with Classic RTA

\begin{tabular}{|c|c|c|c|c|c|c|c|c|c|c|}
\hline \multirow{2}{*}{$\begin{array}{l}\text { Patient, } \\
\text { sex, age, } \\
\text { height, } \\
\text { weight }\end{array}$} & \multirow[b]{2}{*}{ Clinical diagnosis } & \multirow[b]{2}{*}{$\mathrm{C}_{\text {In }}$} & \multicolumn{3}{|c|}{ Urinary acidification* } & \multirow{2}{*}{$\begin{array}{c}\text { 100. } \text { CHCOs }^{-} / \mathrm{C}_{\mathrm{In}} \\
\text { at } \\
\text { normal } \\
{\left[\mathrm{HCO}_{3}^{-}\right] \mathrm{p}}\end{array}$} & \multirow{2}{*}{$\begin{array}{l}\text { Alkali } \\
\text { require- } \\
\text { ment }\end{array}$} & \multirow[b]{2}{*}{$\alpha$-Amino } & \multirow[b]{2}{*}{ Nitrogen } & \multirow[b]{2}{*}{$\begin{array}{c}\text { Additional } \\
\text { diagnoses }\end{array}$} \\
\hline & & & $\begin{array}{l}\mathrm{UpH} \min \\
(\mathrm{tCO})\end{array}$ & $\mathrm{U}_{\mathrm{TA}} \mathrm{V}_{\max }$ & $\underset{\mathrm{V}_{\text {max }}}{\mathrm{U}_{\mathrm{NH}}^{+}}$ & & & & & \\
\hline$y r, c m, k g$ & & $\begin{array}{l}\mathrm{ml} / \mathrm{min} \\
\mathrm{per} \\
1.73 \mathrm{~m}^{2}\end{array}$ & & $\mu \mathrm{mol} / \mathrm{min}$ & & $\%$ & $\begin{array}{c}\text { mmol } \\
\text { per } \\
k g B W\end{array}$ & $\begin{array}{l}m g \text { per } \\
24 \mathrm{~h}\end{array}$ & $\begin{array}{c}\text { g per } \\
\text { g creat } N\end{array}$ & \\
\hline $\begin{array}{l}\text { Normal values } \\
\text { Adult subjects } \\
\text { Children }\end{array}$ & & & $\begin{array}{l}<5.31 \\
<5.60\end{array}$ & $\begin{array}{l}>25.0 \\
>13.9\end{array}$ & $\begin{array}{l}>39.0 \\
>45.7\end{array}$ & & & $50-150$ & $0.30-0.62$ & \\
\hline $\begin{array}{l}\text { C. V., F, } 66 . \\
162,49\end{array}$ & Sjogren's syndrome & 49 & $\begin{array}{l}6.48 \\
(13.0)\end{array}$ & 12.9 & 28.1 & $\begin{array}{c}2.4 \pm 0.3 \\
(22.6 \pm 0.4)\end{array}$ & $1-1.5$ & 90 & & $\begin{array}{l}\text { Nephrocalcinosis } \\
\text { Chronic UTI }\end{array}$ \\
\hline $\begin{array}{c}\text { M. P., F, 45, } \\
156,46\end{array}$ & $\begin{array}{l}\text { Familial classic } \\
\text { RTA (family I) }\end{array}$ & 116 & $\begin{array}{r}6.32 \\
(19.0)\end{array}$ & 11.2 & 21.8 & $\begin{array}{c}2.4 \pm 0 \\
(21.5 \pm 1.3)\end{array}$ & $1-1.5$ & 118 & & $\begin{array}{l}\text { Nephrocalcinosis } \\
\text { Chronic UTI }\end{array}$ \\
\hline $\begin{array}{l}\text { Le. S., F, } 44 \text {. } \\
147,64\end{array}$ & $\begin{array}{l}\text { Familial classic } \\
\text { RTA (family II) }\end{array}$ & 78 & $\begin{array}{r}6.59 \\
(15.5)\end{array}$ & 14.3 & 59.1 & $\begin{array}{c}4.0 \pm 1.5 \\
(23.4 \pm 1.2)\end{array}$ & 1.5 & 132 & & $\begin{array}{l}\text { Nephrocalcinosis } \\
\text { Chronic UTI }\end{array}$ \\
\hline $\begin{array}{l}\text { A. B., F, 39, } \\
144,62\end{array}$ & $\begin{array}{l}\text { Idiopathic hyper- } \\
\text { gammaglobulinemia }\end{array}$ & 76 & $\begin{array}{r}6.77 \\
(14.5)\end{array}$ & 9.3 & 34.6 & $\begin{array}{r}2.1 \pm 0.3 \\
(23.4 \pm 1.5)\end{array}$ & 1.5 & 114 & & \\
\hline $\begin{array}{l}\text { A. P., F, } 37 \\
159,93\end{array}$ & Sjogren's syndrome & 74 & $\begin{array}{r}6.72 \\
(15.7)\end{array}$ & 8.2 & 27.1 & - & $1-2$ & 171 & & \\
\hline $\begin{array}{l}\text { L. W., F, 22, } \\
141,38\end{array}$ & $\begin{array}{l}\text { Familial classic } \\
\text { RTA (family II) }\end{array}$ & 89 & $\begin{array}{r}6.79 \\
(16.5)\end{array}$ & 7.7 & 23.1 & $\begin{array}{r}3.6 \pm 0.3 \\
(23.0 \pm 0.7)\end{array}$ & $2-3$ & 78 & & Nephrocalcinosis \\
\hline $\begin{array}{l}\text { L. S., M, 16, } \\
156,48\end{array}$ & $\begin{array}{l}\text { Familial classic } \\
\text { RTA (family II) }\end{array}$ & 96 & $\begin{array}{r}6.17 \\
(17.5)\end{array}$ & 26.9 & 62.2 & $\begin{array}{c}0.4 \pm 0.3 \\
(22.9 \pm 1.6)\end{array}$ & 1 & 146 & & \\
\hline $\begin{array}{c}\text { C. G., F, 13, } \\
149,50\end{array}$ & $\begin{array}{l}\text { Idiopathic classic } \\
\text { RTA }\end{array}$ & 106 & $\begin{array}{r}6.65 \\
(14.1)\end{array}$ & 17.3 & 17.1 & $\begin{array}{c}2.0 \pm 0.2 \\
(23.9 \pm 0.7)\end{array}$ & $1-1.5$ & 54 & & Nephrocalcinosis \\
\hline $\begin{array}{l}\text { R. C., M, } 13 \text {, } \\
140,35\end{array}$ & $\begin{array}{l}\text { Familial classic } \\
\text { RTA (family III) }\end{array}$ & 121 & $\begin{array}{r}7.20 \\
(17.5)\end{array}$ & 6.2 & 18.3 & $\begin{array}{c}3.4 \pm 0.6 \\
(23.2 \pm 0.9)\end{array}$ & $2-3$ & & 0.31 & \\
\hline $\begin{array}{l}\text { M. S., M, 8, } \\
130,28\end{array}$ & $\begin{array}{l}\text { Familial classic } \\
\text { RTA (family III) }\end{array}$ & 85 & $\begin{array}{r}6.79 \\
(10.4)\end{array}$ & 19.4 & 32.9 & $\begin{array}{c}5.0 \pm 0.2 \\
(24.9 \pm 0.3)\end{array}$ & $2-3$ & & 0.34 & Nephrocalcinosis \\
\hline
\end{tabular}

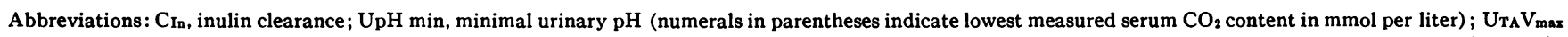

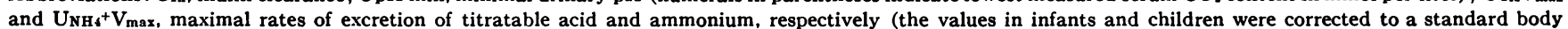

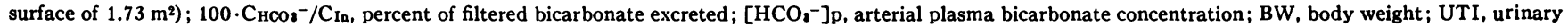
tract infection.

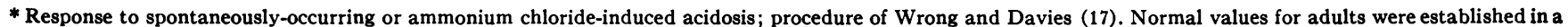

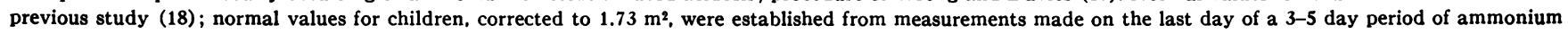
chloride-induced acidosis in children aged 1-16 yr (19).

For each study, the intake of sodium during the period of sodium restriction was taken as the measured sodium content of the diet (mean of two samples of homogenized diet). When the content of sodium was measured in more than one reproduced diet for a study, the intake of sodium was taken as the mean of all the values of measured sodium content. The range of variation of content of measured sodium in repeated reproductions of the same diet was 0-2.7 meq (Table II). In the study on C. V. and in the second study on A. B., the measured sodium content of a duplicate of the original diet used in the study and the measured sodium content of the diet reproduced 8 mo before (A. B.) and $3 \mathrm{yr}$ after (C. V.) study differed less than $1.5 \mathrm{meq}$ (Table II), a value within the range of variation of measured sodium content in repeated reproduction of the same diet. Accordingly, in patients in whom duplicates of the original diets were not analyzed, the intake of sodium during the period of study probably differed no more than
2-3 meq from the amount of sodium measured in the same diet reproduced at a later time.

For each of the 17 diets analyzed, the difference between the measured amount of sodium and the content of sodium estimated from food composition tables was $1.4 \pm 1.4 \mathrm{meq}$ $\mathrm{SD}(n=32)$. Individual differences between measured and estimated sodium content ranged from -0.9 to +4.7 , a range greater than that observed in measured sodium content when the same diet was reproduced more than once. Accordingly, for each study the intake of sodium was likely to be closer to the measured amount of sodium in the diet reproduced subsequently than to the estimated amount in the original diet.

\section{RESULTS}

Urinary excretion of sodium. In each of the $10 \mathrm{pa}$ tients studied, the rate of urinary excretion of sodium 
decreased promptly when sodium intake was restricted (Fig. 1). But in three adult patients (C. V., A. B., L. W.) and in one child (C. G.), renal conservation of sodium was clearly impaired: the amount of sodium ex- creted exceeded the measured amount of sodium ingested throughout the 8-10-day period of sodium restriction (Figs. 1 and 2; Tables III and IV). During the final 3 days of the period of sodium restriction, the amount

TABLE II

Dietary Content of Sodium and Chloride

\begin{tabular}{|c|c|c|c|c|c|}
\hline \multirow{2}{*}{$\begin{array}{l}\text { Patient, } \\
\text { date of } \mathrm{Na}^{+} \\
\text {restriction } \\
\text { study }\end{array}$} & \multirow[b]{2}{*}{$\begin{array}{l}\text { Date diet } \\
\text { prepared for } \\
\text { analysis }\end{array}$} & \multicolumn{3}{|c|}{ Sodium content of diet } & \multirow{2}{*}{$\begin{array}{c}\text { Measured } \\
\text { chloride } \\
\text { content } \\
\text { of diet }\end{array}$} \\
\hline & & Measured & Estimated & $\begin{array}{c}\text { Measured } \\
\text { minus } \\
\text { estimated }\end{array}$ & \\
\hline \multirow{3}{*}{$\begin{array}{l}\text { L. W. } \\
\text { Mar. } 70\end{array}$} & & \multicolumn{3}{|c|}{$m e q / d a y$} & $m e q / d a y$ \\
\hline & \multirow{2}{*}{8.15 .74} & 11.7 & 9.6 & +2.1 & 9.0 \\
\hline & & 11.8 & 9.6 & +2.2 & 9.5 \\
\hline \multirow{2}{*}{$\begin{array}{l}\text { L. S. } \\
\text { Aug. } 70\end{array}$} & \multirow{2}{*}{7.30 .74} & 8.7 & 8.6 & +0.1 & 11.7 \\
\hline & & 9.4 & 8.6 & +0.8 & 12.0 \\
\hline \multirow{9}{*}{$\begin{array}{l}\text { C. V. } \\
\text { Nov. } 71\end{array}$} & 11.02 .71 & 12.4 & 12.2 & +0.2 & 11.7 \\
\hline & \multirow[t]{2}{*}{8.15 .74} & 11.3 & 12.2 & -0.9 & 9.4 \\
\hline & & & 12.2 & -0.6 & 9.9 \\
\hline & \multirow{2}{*}{8.26 .74} & 12.2 & 12.2 & 0 & 10.6 \\
\hline & & 12.4 & 12.2 & +0.2 & 9.7 \\
\hline & \multirow{2}{*}{10.11 .74} & 13.4 & 12.2 & +1.2 & 9.2 \\
\hline & & 13.6 & 12.2 & +1.4 & 10.3 \\
\hline & \multirow{2}{*}{4.08 .75} & 11.2 & 12.2 & -1.0 & 8.3 \\
\hline & & 10.9 & 12.2 & -1.3 & 7.9 \\
\hline \multirow{2}{*}{$\begin{array}{l}\text { A. B. } 1 \\
\text { Sept. } 72\end{array}$} & \multirow{2}{*}{7.03 .74} & 10.3 & 8.2 & +2.1 & 9.7 \\
\hline & & 10.3 & 8.2 & +2.1 & 9.7 \\
\hline \multirow{4}{*}{$\begin{array}{l}\text { A. B. } 2 \\
\text { Mar. } 75\end{array}$} & \multirow{2}{*}{3.05 .75} & 9.6 & 8.4 & +1.2 & 9.6 \\
\hline & & 8.8 & 8.4 & +0.4 & 9.2 \\
\hline & \multirow{2}{*}{3.18 .75} & 11.0 & 8.4 & +2.6 & 10.5 \\
\hline & & 10.7 & 8.4 & +2.3 & 10.4 \\
\hline M. P. & 7.03 .74 & 11.3 & 9.1 & +2.2 & 11.2 \\
\hline \multirow{4}{*}{$\begin{array}{l}\text { Le. S. } \\
\text { May } 73\end{array}$} & \multirow{2}{*}{7.16 .74} & 13.7 & 9.0 & +4.7 & 10.2 \\
\hline & & 12.6 & 9.0 & +3.6 & 10.2 \\
\hline & \multirow{2}{*}{8.16 .74} & 11.8 & 9.0 & +2.8 & 10.0 \\
\hline & & 11.9 & 9.0 & +2.9 & 10.3 \\
\hline \multirow{2}{*}{$\begin{array}{l}\text { A. P. } \\
\text { June } 73\end{array}$} & \multirow{2}{*}{8.05 .74} & 9.0 & 8.8 & +1.8 & 9.8 \\
\hline & & 9.3 & 8.8 & +0.5 & 9.6 \\
\hline \multirow{2}{*}{$\begin{array}{l}\text { R. C. } \\
\text { Sept. } 73\end{array}$} & \multirow{2}{*}{ 7.23.74 } & 10.4 & 8.1 & +2.3 & 18.1 \\
\hline & & 11.0 & 8.1 & +2.9 & 16.7 \\
\hline \multirow{2}{*}{$\begin{array}{l}\text { M. S. } \\
\text { Sept. } 73\end{array}$} & \multirow{2}{*}{7.23 .74} & 9.4 & 8.3 & +1.1 & 13.6 \\
\hline & & 9.7 & 8.3 & +1.4 & 14.5 \\
\hline C. G. & 7.30 .74 & 10.6 & 9.4 & +1.2 & 10.9 \\
\hline & & 11.5 & 9.4 & +2.1 & 11.5 \\
\hline & & & Mean $\pm S D$ & $+1.4 \pm 1.4$ & \\
\hline
\end{tabular}




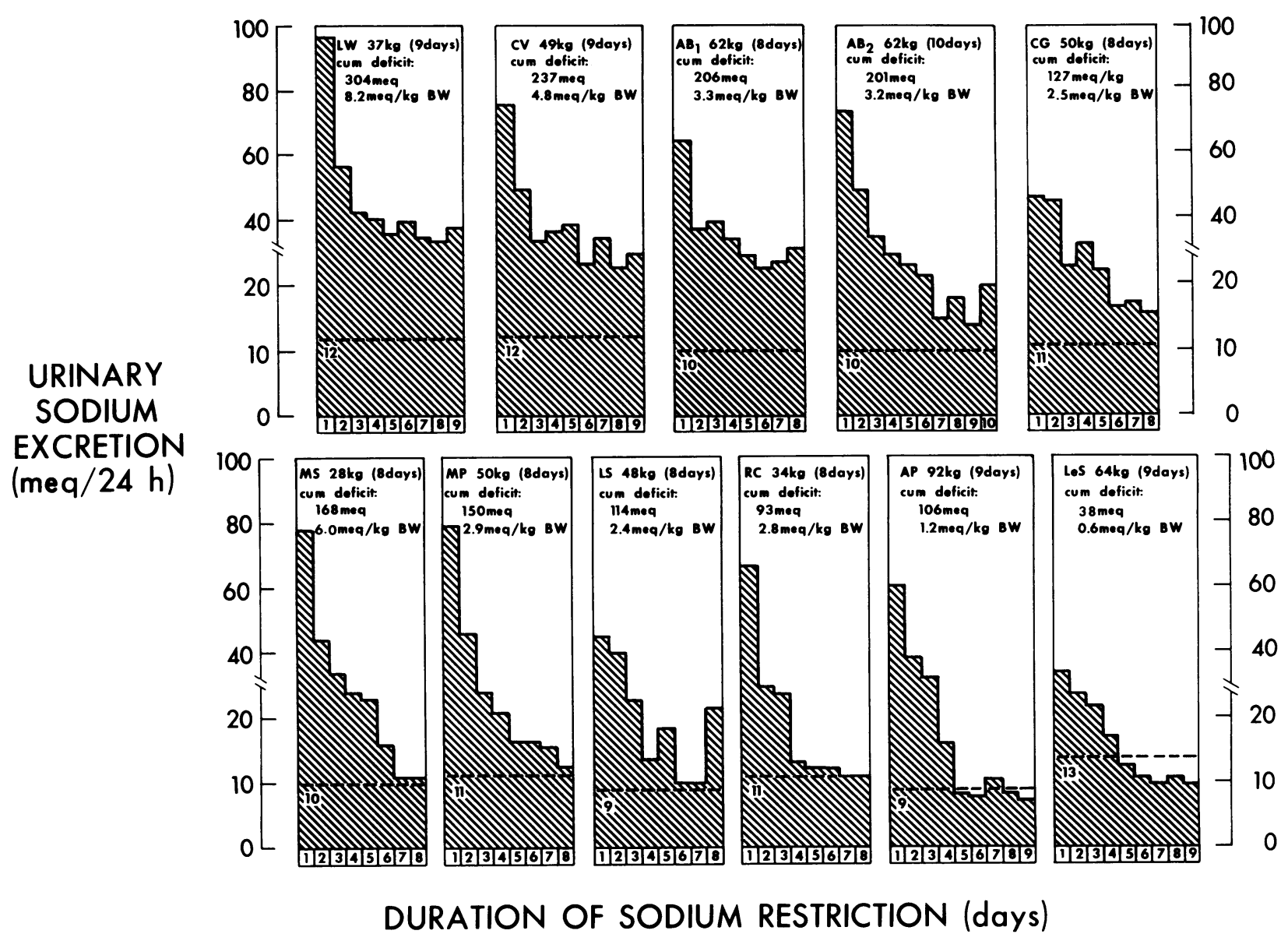

FIGURE 1 Relationship between the urinary excretion rate of sodium and the duration of dietary restriction of sodium in seven adult patients and three children with classic RTA in whom correction of systemic acidosis was sustained by oral administration of potassium bicarbonate. Horizontal dashed lines indicate the measured dietary intake of sodium.

of sodium excreted exceeded the measured amount of sodium ingested by $5-25 \mathrm{meq} /$ day. The differences between the amounts of sodium excreted and ingested exceeded the error (2-3 meq/day) in the determination of dietary sodium content. In three of these patients, the urinary excretion rate of sodium showed no tendency to decline during the final 3 days of the period of sodium restriction (Figs. 1 and 2). In C. V. and A. B. (study no. 2), in whom the content of sodium was measured in the original diet employed in the study, the amount of sodium excreted in the urine during the final 3 days of sodium restriction exceeded the measured amount of sodium ingested by 12-16 meq/day and by 3-9 meq/day, respectively (Fig. 2; Table IV). In the one patient (L. W.) in whom intake of chloride was not restricted concurrently with that of sodium, the failure of urinary sodium excretion to decrease to appropriately low levels did not appear to be a consequence of continued ingestion of chloride. In the one normal subject tested, de- spite continued ingestion of chloride, the urinary excretion rate of sodium decreased promptly to $8 \mathrm{meq} / \mathrm{day}$ when intake of sodium was restricted.

In three adult patients (M. P., Le. S., A. P.) and in two children (R. C., M. S.), renal conservation of sodium appeared to be well-maintained: by the 3rd-8th day of the period of sodium restriction, the amount of sodium excreted in the urine was less than or very nearly equal to the amount of sodium ingested (Fig. 1; Tables III and IV). In two patients (A. P., Le. S.), the urinary excretion rate of sodium decreased to values lower than the measured values of sodium intake (Fig. 1; Table IV). During the final 3 days of the period of sodium restriction in Le. S., the amount of sodium excreted was 2-3 meq/day less than the measured amount of sodium ingested (Fig. 1; Table IV), a characteristic occurrence in normal subjects during dietary restriction of sodium (23-26).

During the control period in most of these studies, 
the balance of sodium appeared to be positive as expected since measurements of stool sodium content were not made (Fig. 2, Tables III and IV). In some studies, the positive balance of sodium appeared unexpectedly large, but this was not prerequisite to the demonstration of impaired renal conservation of sodium (C. V., Fig. 2). In A. B.2 the positive balance of sodium would appear to have been more apparent than real, since it was not associated with weight gain (Fig. 2). With a positive external balance of sodium, one would have expected a weight gain of $0.5-0.8 \mathrm{~kg}$ depending on the estimate of extrarenal losses of sodium. The unexpectedly large positive balances of sodium in the control period might have reflected incomplete absorption of sodium chloride, perhaps related to the unusual intake of potassium bicarbonate.

Among the 10 patients studied, the observed differences in ability to conserve sodium could be correlated with differences in minimal urinary concentration of sodium during sodium restriction: in the adult patients (seven patients), in the children (three patients), and in the combined group of adult patients and children (10 patients), the minimal urinary excretion rates of sodium (values obtained on the final 3 days of sodium re- striction) varied directly with the urinary concentration of sodium (adult patients: $r=0.82, P<0.01$; children : $r=0.85, P<0.01$ ) (Fig. 3). By a similar analysis, the observed differences in ability to conserve sodium could not be shown to be related to differences in urine volume.

Among the 10 patients studied, the observed differences in ability to conserve sodium could not be correlated with the differences in the intake of potassium bicarbonate. The minimal urinary excretion . rates of sodium during the final 3 days of the sodium restriction period did not correlate with the urinary excretion rates of potassium for the same 3 days, whether the excretion rate of potassium was expressed in meq $/ 24 \mathrm{~h}, \mathrm{meq} / \mathrm{kg}$ of body weight per $24 \mathrm{~h}$, or in meq/1.73 $\mathrm{m}^{2}$ per $24 \mathrm{~h}$. By a similar analysis, the minimal urinary excretion rates of sodium did not correlate with the excretion rates of bicarbonate.

Cumulative sodium deficits. In the seven adult patients in whom sodium intake was restricted, differences in ability to conserve sodium were also evident from differences in magnitude of sodium deficit incurred during the period of sodium restriction: in the three adult patients in whom urinary excretion of sodium clearly

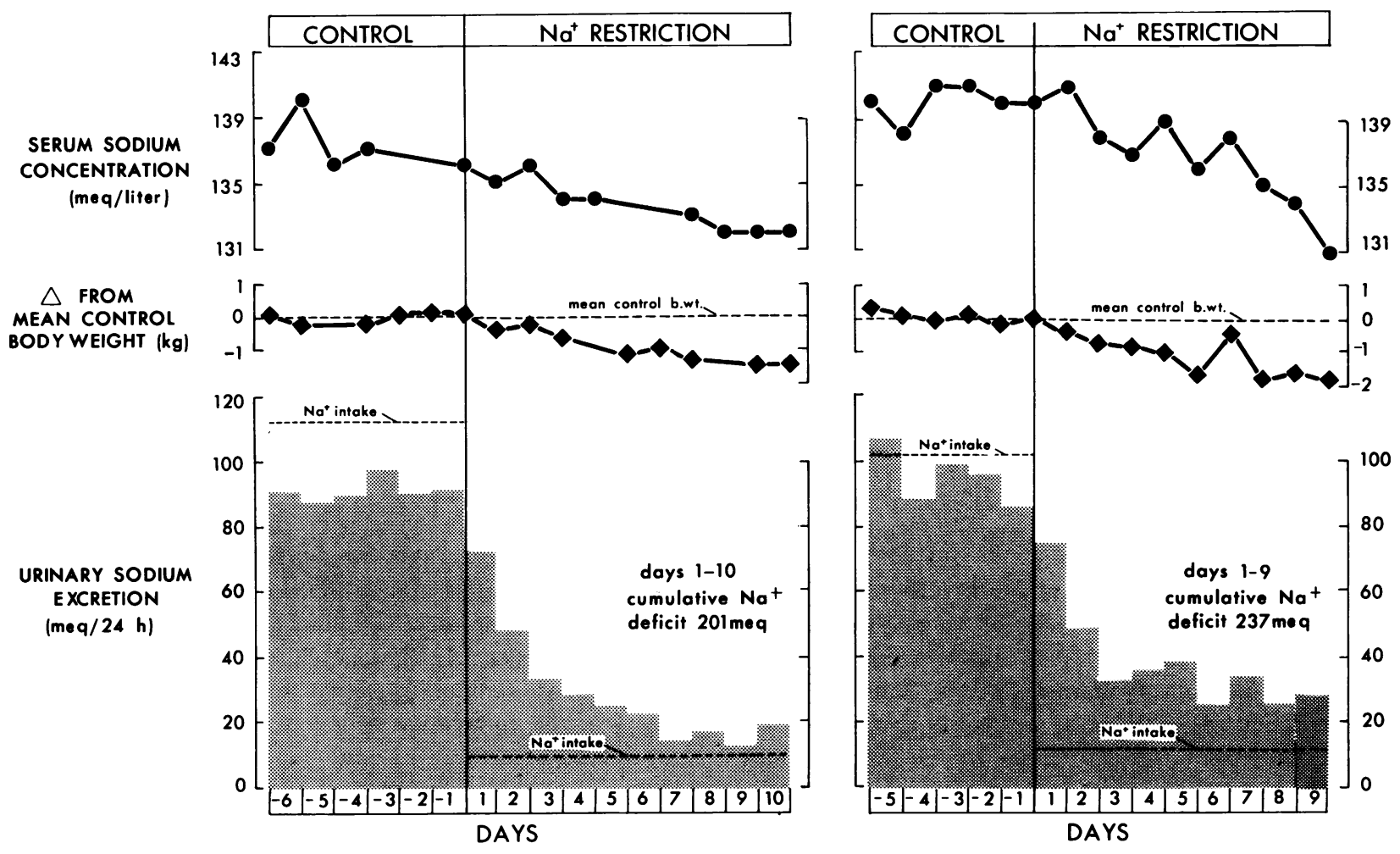

FIgURE 2 Relationships between serum sodium concentration, body weight, and the dietary intake and urinary excretion of sodium before and after restricting sodium intake in two patients (A. B.2, left; C. V., right) with classic RTA in whom correction of systemic acidosis was sustained with potassium bicarbonate therapy. 
TABLE III

Physiological Response to Sodium Restriction During Sustained Correction of Acidosis in Two Patients with Classic RTA: Representative Studies in which Renal Sodium Conservation was Impaired (C. V.) and Well-maintained (Le. S.)

\begin{tabular}{|c|c|c|c|c|c|c|c|c|c|c|c|c|c|c|c|}
\hline \multirow[b]{2}{*}{ Patient } & \multirow{2}{*}{$\begin{array}{c}\text { Study } \\
\text { days }\end{array}$} & \multicolumn{4}{|c|}{ Serum* } & \multirow{2}{*}{$\begin{array}{c}\mathrm{Na}^{+} \\
\text {intake }\end{array}$} & \multirow{2}{*}{$\begin{array}{c}\text { Body } \\
\text { weight }\end{array}$} & \multirow{2}{*}{$\begin{array}{c}\text { Daily } \\
\mathrm{Na}^{+} \\
\text {balance }\end{array}$} & \multicolumn{6}{|c|}{ Urine } & \multirow[b]{2}{*}{$\mathrm{C}_{\text {creat }}$} \\
\hline & & $\mathrm{tCO}_{2}$ & $\mathrm{Cl}^{-}$ & $\mathbf{K}^{+}$ & $\mathrm{Na}^{+}$ & & & & $\mathrm{Na}^{+}$ & $\mathrm{Cl}^{-}$ & $\mathrm{K}^{+}$ & $\mathrm{HCO}_{3}^{-}$ & $\mathrm{pH}$ & Flow & \\
\hline & & \multicolumn{4}{|c|}{$m e q / l$} & $m e q / 24 h$ & $k g$ & $m e q$ & \multicolumn{5}{|c|}{$m e q / 24 h$} & $m l / 24 h$ & $m l / \min$ \\
\hline \multirow{6}{*}{ Le. S. } & Control & & & & & & & & & & & & & & \\
\hline & 1 & 26.8 & 106 & 4.3 & 139 & 103 & 64.2 & +1 & 102 & 96 & 138 & 50.0 & 7.32 & 4,000 & 64 \\
\hline & 2 & & 104 & 4.6 & 141 & 103 & 64.2 & -22 & 125 & 118 & 148 & 55.7 & 7.36 & 4,530 & 67 \\
\hline & 3 & & & & & 103 & 64.2 & +9 & 94 & 92 & 144 & 48.2 & 7.34 & 4,268 & 63 \\
\hline & 4 & 25.8 & 107 & 4.8 & 142 & 103 & 63.6 & +17 & 86 & 82 & 147 & 44.0 & 7.26 & 4,550 & 63 \\
\hline & 5 & 26.1 & 107 & 4.4 & 139 & 103 & 63.8 & +15 & 88 & 90 & 141 & 43.4 & 7.21 & 3,810 & 61 \\
\hline \multicolumn{16}{|c|}{ Restricted sodium } \\
\hline & 1 & 27.3 & 105 & 4.6 & 141 & 13 & 64.0 & -21 & 34 & 37 & 128 & 34.5 & 7.20 & 3,710 & 59 \\
\hline & 2 & 26.8 & 104 & 4.1 & 141 & 13 & 63.6 & -15 & 28 & 25 & 131 & 46.5 & 7.33 & 4,510 & 67 \\
\hline & 3 & 25.8 & 102 & 4.1 & 140 & 13 & 63.5 & -10 & 23 & 26 & 146 & 46.3 & 7.20 & 4,250 & 63 \\
\hline & 4 & & 111 & 4.0 & 141 & 13 & 63.6 & -1 & 14 & 16 & 140 & 43.6 & 7.25 & 4,100 & 57 \\
\hline & 5 & & & & & 13 & 63.6 & 0 & 13 & 13 & 131 & 37.8 & 7.24 & 3,570 & 60 \\
\hline & 6 & & 105 & 4.3 & 141 & 13 & 63.3 & +2 & 11 & 9 & 138 & 40.9 & 7.22 & 4,340 & 60 \\
\hline & 7 & 30.2 & 102 & 4.6 & 139 & 13 & 63.2 & +3 & 10 & 8 & 115 & 40.7 & 7.29 & 3,910 & 47 \\
\hline & 8 & 29.8 & 105 & 4.5 & 142 & 13 & 62.8 & +2 & 11 & 6 & 138 & 43.3 & 7.17 & 4,250 & 52 \\
\hline & 9 & 29.2 & 103 & 4.1 & 141 & 13 & 63.0 & +3 & 10 & 4 & 136 & 47.0 & 7.24 & 4,050 & 60 \\
\hline \multirow[t]{6}{*}{ C. V. } & Control & & & & & & & & & & & & & & \\
\hline & 1 & 25.0 & 104 & 4.4 & 140 & 102 & 49.1 & -5 & 107 & 101 & 117 & 10.2 & 7.24 & 1,975 & \\
\hline & 2 & 24.0 & 100 & 4.5 & 138 & 102 & 48.9 & +14 & 88 & 86 & 107 & 20.7 & 7.17 & 1,800 & 56 \\
\hline & 3 & 28.3 & 101 & 4.6 & 141 & 102 & 48.7 & +3 & 99 & 92 & 114 & 30.9 & 7.12 & 1,910 & 58 \\
\hline & 4 & 27.6 & 104 & 4.3 & 141 & 102 & 48.9 & +6 & 96 & 99 & 121 & 26.3 & 7.20 & 1,840 & 51 \\
\hline & 5 & 27.0 & 102 & 4.2 & 140 & 102 & 48.6 & +16 & 86 & 79 & 118 & 21.0 & 7.10 & 1.790 & 57 \\
\hline \multicolumn{16}{|c|}{ Restricted sodium } \\
\hline & 1 & 27.9 & 101 & 4.5 & 140 & 12 & 48.8 & -63 & 75 & 75 & 119 & 22.1 & 6.96 & 2,200 & 41 \\
\hline & 2 & 28.6 & 100 & 4.5 & 141 & 12 & 48.4 & -37 & 49 & 45 & 109 & 21.8 & 7.08 & 1,950 & 47 \\
\hline & 3 & 27.0 & 98 & 4.7 & 138 & 12 & 48.1 & -21 & 33 & 28 & 100 & 17.8 & 7.03 & 1,860 & 42 \\
\hline & 4 & 25.0 & 98 & 4.9 & 137 & 12 & 48.0 & -24 & 36 & 29 & 108 & 19.6 & 7.06 & 1,800 & 34 \\
\hline & 5 & 29.8 & 98 & 4.8 & 139 & 12 & 47.8 & -27 & 39 & 37 & 117 & 24.2 & 7.19 & 2,050 & 41 \\
\hline & 6 & 30.2 & 96 & 4.9 & 136 & 12 & 47.2 & -14 & 26 & 26 & 96 & 20.0 & 7.27 & 1,650 & 28 \\
\hline & 7 & 29.9 & 97 & 4.8 & 138 & 12 & 48.4 & -22 & 34 & 40 & 117 & 27.2 & 7.22 & 2,020 & 35 \\
\hline & 8 & 25.0 & 95 & 4.9 & 135 & 12 & 47.0 & -13 & 25 & 27 & 107 & 27.7 & 7.25 & 1,820 & 39 \\
\hline & 9 & 29.8 & 93 & 5.1 & 134 & 12 & 47.2 & -17 & 29 & 28 & 105 & 22.6 & 7.20 & 1,840 & 30 \\
\hline
\end{tabular}

Abbreviations: $\mathrm{tCO}_{2}$, total carbon dioxide; $\mathrm{C}_{\text {oreat, }}$ creatinine clearance.

* Acid-base status of arterial blood, see Table IV.

$\ddagger$ Calculated by subtracting urinary excretion from dietary intake of sodium.

failed to decrease to appropriately low levels (C. V., A. B., L. W.), the cumulative deficit of sodium during the first 8 days of sodium restriction exceeded that incurred by normal subjects during a period of sodium restriction of similar duration that follows a prerestriction control period of similar dietary intake of sodium (5, 23-26) (Fig. 4). By contrast, in two of the three adult patients in whom renal conservation of sodium appeared to be well-maintained (Le. S., A. P.), the cumulative deficit of sodium was similar to that incurred by normal subjects (Fig. 4). In one of the three adult patients who appeared to conserve sodium well (M. P.), however, the cumulative deficit of sodium exceeded that incurred by normal subjects by at least 10 meq (Fig. 4). But the cumulative deficit of sodium might have been overestimated by as much as 16-24 meq, since the intake of sodium for the 8 days of study might have been as much as $2-3 \mathrm{meq} /$ day greater than the measured value. Of the three children studied, in the one child in whom urinary sodium excretion clearly failed to decrease to appropriately low levels during the period of sodium restriction (C. G.), the cumulative deficits of sodium nearly exceeded the upper limits of adult normal subjects during a period of sodium restriction of similar duration (Fig. 4). In the one child in whom renal conservation of sodium appeared to be well-maintained (M. S.), the cumulative deficit of sodium exceeded the upper limit of normal for adult subjects by 20 meq (Fig. 4). Although the calculated cumulative deficit of sodium in this child could be reduced to the upper values of the normal range of adult subjects by correcting for the potential error in the measured dietary intake of sodium, the magnitude of the deficit still may be inordinately large for a child. 
Urinary chloride excretion. In the eight patients in whom intake of chloride was restricted concurrently with the intake of sodium, the ability to conserve chloride appeared to be normal in only three patients (Le. S.,
R. C., M. S.), each of whom also appeared to conserve sodium well: in these patients, by the 5 th-7th day of the period of chloride restriction, the amount of chloride excreted in the urine was slightly less than the amount

TABLE IV

Physiological Response to Sodium Restriction during Sustained Correction of Acidosis in Patients with Classic RTA: Summary of Results

\begin{tabular}{|c|c|c|c|c|c|c|c|c|c|c|c|c|}
\hline \multirow[b]{2}{*}{ Patient } & \multirow[b]{2}{*}{ Study periods } & \multicolumn{2}{|c|}{ Serum* } & \multirow{2}{*}{$\begin{array}{c}\mathrm{Na}^{+} \\
\text {intake }\end{array}$} & \multirow{2}{*}{$\begin{array}{c}\text { Body } \\
\text { weight }\end{array}$} & \multirow{2}{*}{$\begin{array}{l}\text { Urinary } \\
\text { aldo- } \\
\text { sterone }\end{array}$} & \multirow{2}{*}{$\begin{array}{l}\text { Cumula- } \\
\text { tive } \mathrm{Na}^{+} \\
\text {deficit }\end{array}$} & \multicolumn{4}{|c|}{ Urinef } & \multirow[b]{2}{*}{$C_{\text {creat }}$} \\
\hline & & $\mathrm{K}^{+}$ & $\mathrm{Na}^{+}$ & & & & & $\mathrm{Na}^{+}$ & $\mathrm{Cl}^{-}$ & $\mathrm{K}^{+}$ & Flow & \\
\hline & & \multicolumn{2}{|c|}{ meq/liter } & $m e q / 24 h$ & $k g$ & $\begin{array}{l}\mu g / 24 h \\
\text { per } \\
1.73 \mathrm{~m}^{2}\end{array}$ & meq & & $m e q / 24 h$ & & liter $/ 24 h$ & $m l / m i n$ \\
\hline C. V. & $\begin{array}{l}\text { Control } \\
\text { Low sodium }(9) \S\end{array}$ & $\begin{array}{l}4.4 \pm 0.2 \\
4.9 \pm 0.1\end{array}$ & $\begin{array}{l}140 \pm 1 \\
136 \pm 2\end{array}$ & $\begin{array}{r}102 \\
12\end{array}$ & $\begin{array}{l}48.8 \\
47.2\end{array}$ & $\begin{array}{r}60 \\
134\end{array}$ & 237 & $\begin{array}{c}90 \pm 8 \\
34 \\
25 \\
29\end{array}$ & $\begin{array}{c}89 \pm 8 \\
40 \\
27 \\
28\end{array}$ & $\begin{array}{c}116 \pm 6 \\
117 \\
107 \\
105\end{array}$ & $\begin{array}{c}1.84 \pm 0.05 \\
2.02 \\
1.82 \\
1.84\end{array}$ & $\begin{array}{l}56 \pm 3 \\
33 \pm 5\end{array}$ \\
\hline M. P. & $\begin{array}{l}\text { Control } \\
\text { Low sodium (8) }\end{array}$ & $\begin{array}{l}4.9 \pm 0.1 \\
4.7 \pm 0.1\end{array}$ & $\begin{array}{l}139 \pm 2 \\
140 \pm 1\end{array}$ & $\begin{array}{r}101 \\
11\end{array}$ & $\begin{array}{l}50.4 \\
48.8\end{array}$ & $\begin{array}{r}36 \\
117\end{array}$ & 150 & $\begin{array}{c}65 \pm 14 \\
16 \\
16 \\
13\end{array}$ & $\begin{array}{c}68 \pm 17 \\
12 \\
15 \\
12\end{array}$ & $\begin{array}{c}148 \pm 17 \\
146 \\
149 \\
147\end{array}$ & $\begin{array}{c}2.19 \pm 0.14 \\
2.06 \\
2.27 \\
2.10\end{array}$ & $\begin{array}{l}71 \pm 6 \\
64 \pm 6\end{array}$ \\
\hline Le. S. & $\begin{array}{l}\text { Control } \\
\text { Low sodium (9) }\end{array}$ & $\begin{array}{l}4.6 \pm 0.2 \\
4.4 \pm 0.2\end{array}$ & $\begin{array}{l}141 \pm 2 \\
141 \pm 1\end{array}$ & $\begin{array}{r}103 \\
13\end{array}$ & $\begin{array}{l}63.8 \\
63.0\end{array}$ & $\begin{array}{l}33 \\
55\end{array}$ & 38 & $\begin{array}{c}98 \pm 18 \\
10 \\
11 \\
10\end{array}$ & $\begin{array}{c}96 \pm 16 \\
8 \\
6 \\
4\end{array}$ & $\begin{array}{c}145 \pm 3 \\
115 \\
138 \\
136\end{array}$ & $\begin{array}{c}4.29 \pm 0.35 \\
3.91 \\
4.25 \\
4.05\end{array}$ & $\begin{array}{l}64 \pm 3 \\
55 \pm 6\end{array}$ \\
\hline A. B.1 & $\begin{array}{l}\text { Control } \\
\text { Low sodium (8) }\end{array}$ & $\begin{array}{l}4.4 \pm 0.3 \\
4.2 \pm 0.1\end{array}$ & $\begin{array}{l}132 \pm 1 \\
132 \pm 3\end{array}$ & $\begin{array}{r}115 \\
10\end{array}$ & $\begin{array}{l}62.3 \\
61.2\end{array}$ & $\begin{array}{l}30 \\
75\end{array}$ & 206 & $\begin{array}{c}107 \pm 21 \\
25 \\
27 \\
31\end{array}$ & $\begin{array}{c}112 \pm 18 \\
20 \\
23 \\
28\end{array}$ & $\begin{array}{c}142 \pm 16 \\
146 \\
176 \\
151\end{array}$ & $\begin{array}{c}2.33 \pm 0.44 \\
1.54 \\
2.09 \\
1.84\end{array}$ & $\begin{array}{l}74 \pm 15 \\
68 \pm 7\end{array}$ \\
\hline A. B.2 & $\begin{array}{l}\text { Control } \\
\text { Low sodium (10) }\end{array}$ & $\begin{array}{l}4.5 \pm 0.4 \\
4.5 \pm 0.1\end{array}$ & $\begin{array}{l}137 \pm 1 \\
132 \pm 1\end{array}$ & $\begin{array}{r}112 \\
10\end{array}$ & $\begin{array}{l}62.0 \\
60.5\end{array}$ & $\begin{array}{l}23 \\
53\end{array}$ & 201 & $\begin{array}{c}92 \pm 4 \\
18 \\
14 \\
20\end{array}$ & $\begin{array}{c}97 \pm 8 \\
17 \\
14 \\
15\end{array}$ & $\begin{array}{c}136 \pm 4 \\
131 \\
135 \\
141\end{array}$ & $\begin{array}{c}1.46 \pm 0.13 \\
1.14 \\
1.20 \\
1.30\end{array}$ & $\begin{array}{l}57 \pm 1 \\
53 \pm 9\end{array}$ \\
\hline A. $\mathbf{P}$. & $\begin{array}{l}\text { Control } \\
\text { Low sodium (9) }\end{array}$ & $\begin{array}{l}4.4 \pm 0.1 \\
3.9 \pm 0.5\end{array}$ & $\begin{array}{l}141 \pm 1 \\
142 \pm 2\end{array}$ & $\begin{array}{r}69 \\
9\end{array}$ & $\begin{array}{l}91.8 \\
89.8\end{array}$ & $\begin{array}{r}9 \\
20\end{array}$ & 106 & $\begin{array}{c}66 \pm 36 \\
11 \\
9 \\
8\end{array}$ & $\begin{array}{c}63 \pm 29 \\
15 \\
16 \\
14\end{array}$ & $\begin{array}{c}96 \pm 33 \\
115 \\
118 \\
115\end{array}$ & $\begin{array}{c}1.67 \pm 0.03 \\
1.54 \\
1.49 \\
1.55\end{array}$ & $\begin{array}{l}83 \pm 19 \\
87 \pm 5\end{array}$ \\
\hline L. W. & $\begin{array}{l}\text { Control } \\
\text { Low sodium (9)\| }\end{array}$ & $\begin{array}{l}3.9 \pm 0.1 \\
4.6 \pm 0.2\end{array}$ & $\begin{array}{l}138 \pm 1 \\
135 \pm 1\end{array}$ & $\begin{array}{r}132 \\
12\end{array}$ & $\begin{array}{l}37.4 \\
35.1\end{array}$ & $\begin{array}{r}53 \\
315\end{array}$ & 304 & $\begin{array}{c}119 \pm 13 \\
34 \\
33 \\
37\end{array}$ & $\begin{array}{c}125 \pm 10 \\
57 \\
61 \\
39\end{array}$ & $\begin{array}{c}151 \pm 10 \\
171 \\
173 \\
168\end{array}$ & $\begin{array}{c}2.71 \pm 0.05 \\
2.85 \\
2.87 \\
2.44\end{array}$ & $\begin{array}{l}73 \pm 2 \\
65 \pm 5\end{array}$ \\
\hline L. $\mathbf{S}$. & $\begin{array}{l}\text { Control } \\
\text { Low sodium (8)\| }\end{array}$ & $\begin{array}{l}4.4 \pm 0.1 \\
4.1 \pm 0.1\end{array}$ & $\begin{array}{l}138 \pm 1 \\
137 \pm 1\end{array}$ & $\begin{array}{r}99 \\
9\end{array}$ & $\begin{array}{l}48.1 \\
47.3\end{array}$ & $\begin{array}{r}8 \\
41\end{array}$ & 114 & $\begin{array}{c}88 \pm 14 \\
10 \\
10 \\
23\end{array}$ & $\begin{array}{c}80 \pm 10 \\
40 \\
47 \\
59\end{array}$ & $\begin{array}{c}148 \pm 19 \\
111 \\
139 \\
154\end{array}$ & $\begin{array}{c}1.98 \pm 0.20 \\
2.09 \\
2.05 \\
2.57\end{array}$ & $\begin{array}{l}84 \pm 19 \\
69 \pm 5\end{array}$ \\
\hline C. $\mathbf{G}$. & $\begin{array}{l}\text { Control } \\
\text { Low sodium (8) }\end{array}$ & $\begin{array}{l}4.1 \pm 0.2 \\
3.8 \pm 0.4\end{array}$ & $\begin{array}{l}136 \pm 3 \\
134 \pm 1\end{array}$ & $\begin{array}{r}101 \\
11\end{array}$ & $\begin{array}{l}49.8 \\
47.8\end{array}$ & $\begin{array}{l}43 \\
41\end{array}$ & 127 & $\begin{array}{c}81 \pm 14 \\
16 \\
17 \\
16\end{array}$ & $\begin{array}{c}84 \pm 12 \\
15 \\
18 \\
33\end{array}$ & $\begin{array}{c}114 \pm 17 \\
89 \\
88 \\
87\end{array}$ & $\begin{array}{c}1.73 \pm 0.36 \\
1.37 \\
1.01 \\
1.73\end{array}$ & $\begin{array}{l}78 \pm 10 \\
59 \pm 11\end{array}$ \\
\hline R. C. & $\begin{array}{l}\text { Control } \\
\text { Low sodium (8) }\end{array}$ & $\begin{array}{l}4.0 \pm 0.1 \\
4.6 \pm 0.2\end{array}$ & $\begin{array}{l}142 \pm 2 \\
138 \pm 3\end{array}$ & $\begin{array}{r}111 \\
11\end{array}$ & $\begin{array}{l}33.6 \\
32.4\end{array}$ & $\begin{array}{l}35 \\
70\end{array}$ & 93 & $\begin{array}{c}121 \pm 44 \\
12 \\
11 \\
11\end{array}$ & $\begin{array}{c}108 \pm 38 \\
16 \\
16 \\
12\end{array}$ & $\begin{array}{c}106 \pm 38 \\
141 \\
162 \\
142\end{array}$ & $\begin{array}{c}1.60 \pm 0.04 \\
1.22 \\
1.59 \\
1.34\end{array}$ & $\begin{array}{l}88 \pm 25 \\
75 \pm 10\end{array}$ \\
\hline M. S. & $\begin{array}{l}\text { Control } \\
\text { Low sodium (8) }\end{array}$ & $\begin{array}{l}4.2 \pm 0.1 \\
4.6 \pm 0.1\end{array}$ & $\begin{array}{l}142 \pm 1 \\
140 \pm 1\end{array}$ & $\begin{array}{l}70 \\
10\end{array}$ & $\begin{array}{l}28.1 \\
27.3\end{array}$ & $\overline{139}$ & 168 & $\begin{array}{c}93 \pm 17 \\
16 \\
11 \\
11\end{array}$ & $\begin{array}{c}69 \pm 15 \\
22 \\
12 \\
10\end{array}$ & $\begin{array}{c}98 \pm 25 \\
131 \\
127 \\
128\end{array}$ & $\begin{array}{c}1.10 \pm 0.04 \\
1.12 \\
1.00 \\
1.14\end{array}$ & $\begin{array}{l}74 \pm 6 \\
69 \pm 13\end{array}$ \\
\hline
\end{tabular}

* Mean \pm SD of values obtained on the 4 final days of the control and low sodium periods.

$\$$ Mean \pm SD of values obtained on the 4 final days of the control period; individual values obtained on the 3 final days of the low sodium period.

Numerals in parentheses indicate the duration in days of the period of sodium restriction.

|l Intake of chloride not restricted concurrently with restriction of sodium intake. 


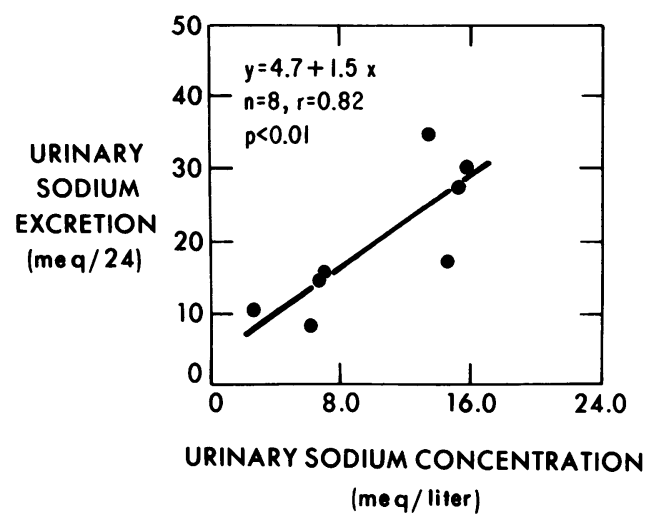

Figure 3 Relationship between urinary excretion rate and urinary concentration of sodium during the final 3 days of an 8-10 day period of sodium restriction in eight studies of seven adult patients with classic RTA in whom correction of systemic acidosis was sustained by oral administration of potassium bicarbonate.

of chloride ingested (Fig. 5 ; Tables III and IV). Renal conservation of chloride was clearly impaired, however, in four of the remaining five patients, one of whom conserved sodium well (A. P.) and three of whom did not (C. V., A. B., C. G.). In each of the four patients, urinary excretion of chloride exceeded dietary intake of chloride throughout the period of chloride restriction (Fig. 5; Tables III and IV). In the three patients in whom renal conservation of both chloride and sodium was clearly impaired (C. V., A. B., C. G.) (Fig. 5), the rates of excretion of chloride and sodium were nearly identical throughout the restriction period: hence, the impairment in renal conservation of chloride and the impairment in renal conservation of sodium were of similar severity.

Relationship between urinary concentration and excretion rate of sodium and urine flow during experimentally induced water diuresis. The urinary concentration of sodium decreased as urine flow increased in each of six patients with classic RTA (L. W., M. P., Le. S., A. B., M. S., R. C.) in whom a water diuresis was induced at the end of the period of sodium restriction (Fig. 6A). Except in L. W., most of the decrease in urinary concentration of sodium occurred as urine flow increased to values $1-2 \mathrm{ml} / \mathrm{min}$ greater than the base-line values; as urine flow increased further, the urinary concentration of sodium remained constant or decreased only slightly. Because in each patient the decrease in concentration of sodium was not proportional to the increase in urine flow, the rate of excretion of sodium increased as urine flow increased (Fig. 6B). These findings are similar to those observed by other investigators in sodium-depleted normal subjects undergoing a water diuresis (27); the urinary concentrations and excretion rates of sodium in sodium-depleted normal subjects, however, appear to be generally lower than those observed in the patients with RTA (Figs. 6A and B).

Acid-base status. In each patient, correction of systemic acidosis was sustained throughout control and sodium restriction periods (Table $V$ ). In six patients, two of whom had markedly impaired renal conservation of sodium, the $\mathrm{pH}$ of the urine was greater than the $\mathrm{pH}$ of arterial blood during the period of sodium restriction. The $\mathrm{pH}$ of the urine was slightly less than that of arterial blood in four patients, in one of whom (C. V.) renal conservation of sodium was clearly impaired, and in two of whom (Le. S., A. P.) it was well-maintained. Differences in ability to conserve sodium appeared to be unrelated to the magnitude of bicarbonaturia during the period of sodium restriction (Table V).

\section{DISCUSSION}

RTA is a clinical syndrome of disordered renal acidification characterized biochemically by minimal or no azotemia, hyperchloremic acidosis, inappropriately high urinary $\mathrm{pH}$, bicarbonaturia, and reduced urinary excre-

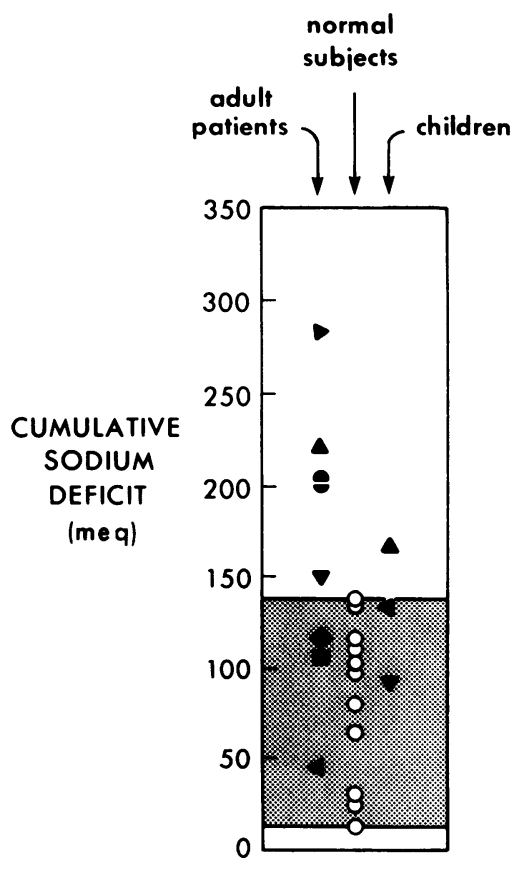

FIGURE 4 Cumulative deficits of sodium during dietary restriction of sodium in patients with classic RTA (closed symbols) and in normal subjects (open circles, shaded zone). For purposes of comparison, values in the patients represent the deficit of sodium incurred during the first 8 days of dietary restriction of sodium. Values in normal subjects represent the cumulative deficit of sodium incurred in adult subjects during 6 or 8 days of dietary restriction of sodium (23-26). Adult patients : $\Delta$ C. V.; $\nabla$ M. P.; $\backslash$ Le. S. ; A. B.1; A. B.2; A. P.; L. W.; L. S. Children: $\neg$ C. G.; $\nabla$ R. C. ; $\triangle$ M. S. 


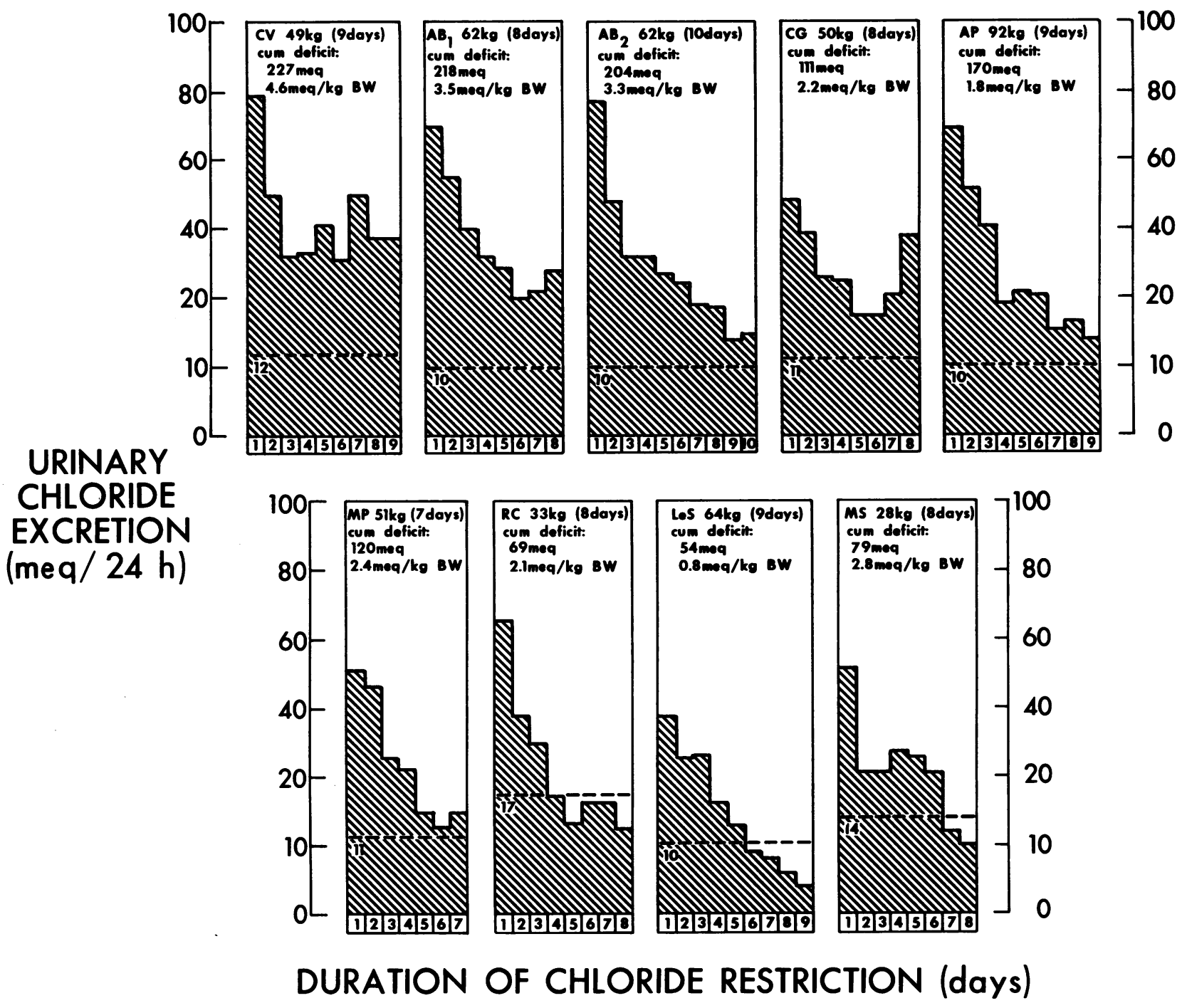

FIGURE 5 Relationship between the urinary excretion rate of chloride and the duration of dietary restriction of chloride in five adult patients and three children with classic RTA in whom correction of systemic acidosis was sustained by oral administration of potassium bicarbonate. Horizontal dashed lines indicate the measured dietary intake of chloride.

iton rates of titratable acid and ammonium $(1,2,6,8$, $10,11,13,17,18,21,28-33)$. In patients with classic RTA (type 1, "distal" RTA), the $\mathrm{pH}$ of the urine remains inappropriately high during severe as well as mild degrees of acidosis (Table I), and persisting bicarbonaturia is characteristic $(8,11,21)$. In adult patients with classic RTA, the amount of bicarbonate excreted is a very small fraction of that filtered at normal as well as at reduced plasma bicarbonate concentrations (Table I) $(6,13,18,21,29,30)$. Hence, net renal reabsorption of filtered bicarbonate is not substantially reduced. The dysfunction of renal acidification in classic RTA has been inferred to be the consequence of an inability of the distal segments of the nephron to generate or maintain appropriately steep luminal-to-peritubular fluid hydrogen ion concentration gradients $(13,17,30$, 33).

Untreated patients with classic RTA fail to conserve sodium as well as normal subjects when dietary intake of sodium is restricted; depletion of sodium and secondary hyperaldosteronism persist even when dietary intake of sodium is maintained at normal levels $(4,5)$. The impairment in renal reabsorption of sodium presumed to account for these findings has been inferred to be a reversible consequence of the renal acidification defect $(5,11,13)$. The inferred gradient-restriction on renal hydrogen ion secretion is presumed to reduce the net rate of $\mathrm{H}^{+}-\mathrm{Na}^{+}$exchange in the distal nephron and 

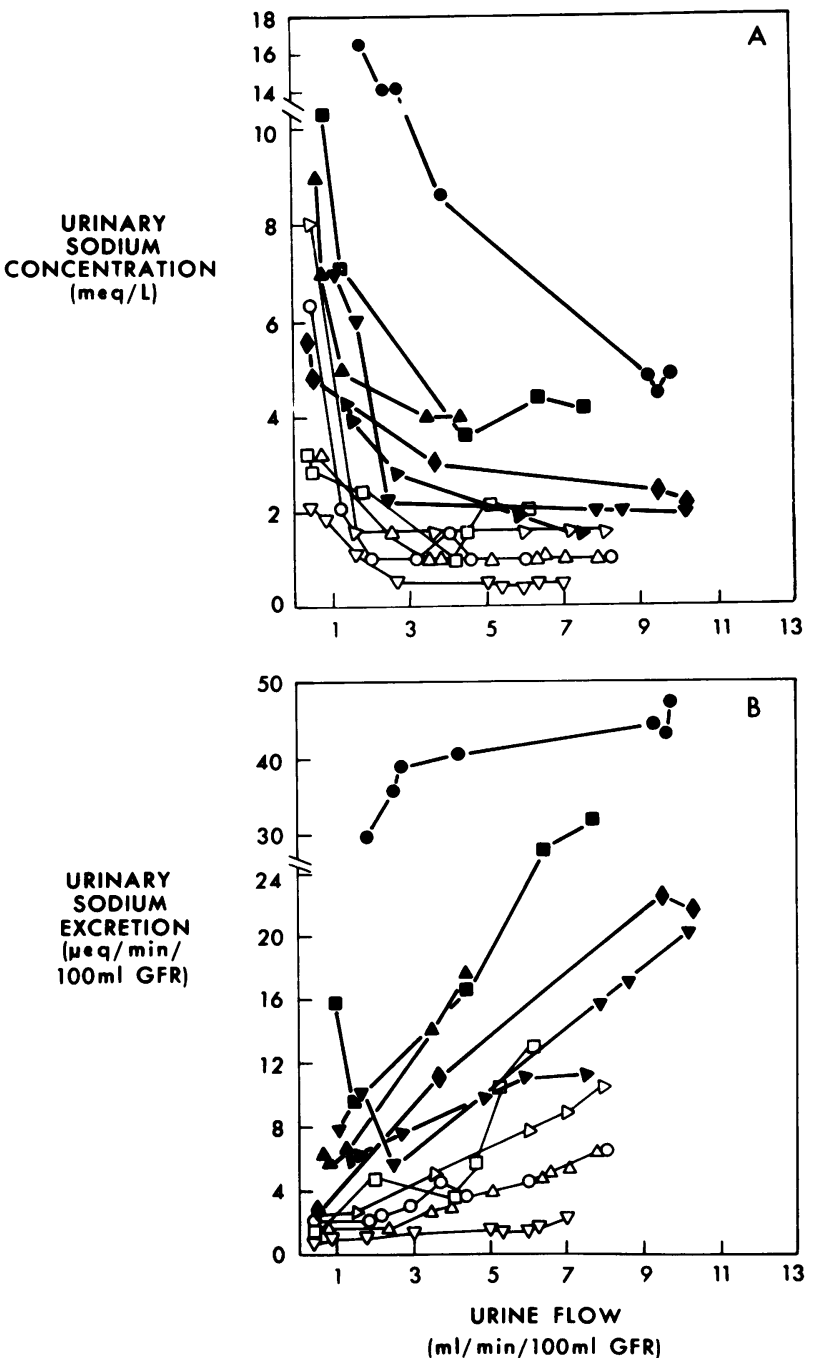

Figure 6 . Relationship between urinary concentration of sodium and urine flow (A) and between urinary excretion rate of sodium and urine flow (B) during sodium depletion and water diuresis in six patients with classic RTA (closed symbols) and five normal subjects (open symbols). - L. W. ; $\Delta$ M. S. ; $\nabla$ M. P. ; $\gg$ R. C. ; Le. S. ; $\square$ A. B. Data on normal subjects was taken from the study by Coleman et al. (27). Values of urine flow are expressed as a fraction of glomerular filtration rate adjusted to $100 \mathrm{ml} / \mathrm{min}$., the assumed glomerular filtration rate of the normal subjects.

thereby impair renal conservation of sodium. This formulation is based upon the observation that in patients with RTA, correction of systemic acidosis with alkali therapy can lead to a reduction of the urinary excretion rate of sodium and to an external balance of sodium sufficiently positive to correct secondary hyperaldosteronism: by increasing intraluminal bicarbonate concentration and $\mathrm{pH}$, correction of acidosis with alkali therapy is presumed to remove the inferred gradient- restriction on hydrogen ion secretion, increase the net rate of $\mathrm{H}^{+}-\mathrm{Na}^{+}$exchange in the distal nephron and thereby correct the impairment in renal conservation of sodium (5).

But the observation that urinary excretion of sodium can decrease, and sodium balance can become positive, in patients with classic RTA when their acidosis is corrected with alkali therapy does not necessarily. indicate that the impairment in renal conservation of sodium evident during acidosis has been corrected (6). The sodium-conserving effect of alkali therapy has been observed only in patients in whom dietary intake of sodium was normal ( $>100 \mathrm{meq} /$ day) and maintained constant; alkali therapy was administered by substituting 100 meq $\mathrm{NaHCO}_{3}$ for an equimolar amount of dietary $\mathrm{NaCl}$ (5). Since under these conditions the urinary excretion rate of sodium must have been substantial $(>100 \mathrm{meq} / \mathrm{day})$ when alkali therapy was initiated, the reduction in urinary excretion of sodium necessary to account for the observed positive cumulative balance of sodium could have been quite modest (e.g., 30-40 meq/day). From the occurrence of such a modest reduction, it could not be confidently predicted that urinary excretion of sodium would decrease to appropriately low rates when the intake of sodium was restricted.

The results of the present study indicate that in at least some patients with classic RTA, renal conservation of sodium is impaired when dietary intake of sodium is restricted during sustained correction of acidosis with alkali therapy. In 4 of 10 patients (L. W., C. V., A. B., C. B.) in whom dietary intake of sodium was restricted, urinary excretion of sodium exceeded dietary intake of sodium by $5-27 \mathrm{meq} /$ day throughout the $8-10$-day period of sodium restriction; in three patients, the excretion of sodium did not diminish further during the latter part of the restriction period. In three of the four patients (C. V., A. B., C. G.), dietary intake of chloride was also restricted, and in these three patients, renal conservation of chloride was also clearly impaired. In addition, in one of the children studied (M. S.) in whom urinary excretion of sodium decreased to levels approximating those of sodium intake during the period of sodium restriction, the cumulative deficit of sodium exceeded that incurred by normal adult subjects during a period of sodium restriction of similar duration. Thus, by at least one criterion, renal conservation of sodium was impaired in $\mathbf{5}$ of the 10 patients studied.

This demonstration of impaired renal conservation of sodium during sustained correction of systemic acidosis provides the first direct evidence of an abnormality in renal tubular reabsorption of sodium in classic RTA. The observation that acidotic patients with classic RTA fail to conserve sodium as well as normal subjects who are not acidotic (5) cannot be interpreted as evidence of 
TABLE V

Acid-Base Status of Blood and Urine Before and During Restriction of Sodium Intake in Patients with Classic RTA

\begin{tabular}{|c|c|c|c|c|c|c|c|c|c|c|}
\hline & & \multicolumn{3}{|c|}{ Arterial blood* } & \multicolumn{2}{|c|}{ Venous serum $\ddagger$} & \multicolumn{4}{|c|}{ Urine§ } \\
\hline & & $\mathrm{pH}$ & $\mathrm{pCO}_{2}$ & {$\left[\mathrm{HCO}_{2}^{-}\right]$} & $\mathrm{tCO}_{2}$ & {$\left[\mathrm{Cl}^{-}\right]$} & $\mathrm{pH}$ & $\mathrm{HCO}_{2}^{-}$ & $\mathrm{HCO}_{2}^{-}$ & $\mathrm{HCO}_{3}^{-}$ \\
\hline & & & $m m H g$ & $\begin{array}{c}\text { mmol/ } \\
\text { liter }\end{array}$ & $\mathrm{mmol} / \mathrm{liter}$ & $\mathrm{mmol} / \mathrm{liter}$ & & $\begin{array}{l}\text { mmol/ } \\
\text { per } 24 h\end{array}$ & $\begin{array}{l}\mathrm{mmol} / \mathrm{per} \\
100 \mathrm{ml} \mathrm{GF}\end{array}$ & $\begin{array}{c}\mathrm{mmol} / \\
\mathrm{kg} \mathrm{BW/24h}\end{array}$ \\
\hline c. v. & $\begin{array}{l}\text { Control } \\
\text { Low sodium }\end{array}$ & 7.42 & 37 & 23.2 & $\begin{array}{l}27.0-28.3 \\
29.8-30.2\end{array}$ & $\begin{array}{c}101-104 \\
93-97\end{array}$ & $\begin{array}{l}7.14 \pm 0.05 \\
7.24 \pm 0.03\end{array}$ & $\begin{array}{l}27.0 \pm 5.0 \\
26.0 \pm 4.7\end{array}$ & $\begin{array}{l}31.0 \pm 6.3 \\
51.3 \pm 2.3\end{array}$ & $\begin{array}{l}0.56 \pm 0.11 \\
0.54 \pm 0.10\end{array}$ \\
\hline M. P. & $\begin{array}{l}\text { Control } \\
\text { Low sodium }\end{array}$ & $\begin{array}{l}7.38 \\
7.42\end{array}$ & $\begin{array}{l}40 \\
39\end{array}$ & $\begin{array}{l}23.0 \\
24.3\end{array}$ & $\begin{array}{l}27.9-28.7 \\
29.8-30.6\end{array}$ & $\begin{array}{l}98-104 \\
95-102\end{array}$ & $\begin{array}{l}7.55 \pm 0.13 \\
7.62 \pm 0.12\end{array}$ & $\begin{array}{l}52.8 \pm 6.5 \\
61.4 \pm 14.7\end{array}$ & $\begin{array}{l}51.4 \pm 8.1 \\
67.5 \pm 22.4\end{array}$ & $\begin{array}{l}1.05 \pm 0.13 \\
1.23 \pm 0.30\end{array}$ \\
\hline Le. $S$. & $\begin{array}{l}\text { Control } \\
\text { Low sodium }\end{array}$ & $\begin{array}{l}7.42 \\
7.41\end{array}$ & $\begin{array}{l}34 \\
38\end{array}$ & $\begin{array}{l}21.4 \\
23.3\end{array}$ & $\begin{array}{l}25.8-26.8 \\
29.2-30.2\end{array}$ & $\begin{array}{l}104-107 \\
101-105\end{array}$ & $\begin{array}{l}7.29 \pm 0.07 \\
7.23 \pm 0.05\end{array}$ & $\begin{array}{l}47.8 \pm 5.6 \\
43.0 \pm 2.9\end{array}$ & $\begin{array}{l}52.2 \pm 4.2 \\
54.9 \pm 5.6\end{array}$ & $\begin{array}{l}0.75 \pm 0.09 \\
0.67 \pm 0.05\end{array}$ \\
\hline A. B.1 & $\begin{array}{l}\text { Control } \\
\text { Low sodium }\end{array}$ & $\begin{array}{l}7.39 \\
7.41\end{array}$ & $\begin{array}{l}44 \\
44\end{array}$ & $\begin{array}{l}25.7 \\
27.0\end{array}$ & $\begin{array}{l}24.9-26.6 \\
25.5-29.3\end{array}$ & $\begin{array}{l}97-101 \\
97-99\end{array}$ & $\begin{array}{l}7.67 \pm 0.08 \\
7.61 \pm 0.06\end{array}$ & $\begin{array}{l}68.7 \pm 7.1 \\
60.3 \pm 7.2\end{array}$ & $\begin{array}{l}71.4 \pm 6.5 \\
61.9 \pm 1.1\end{array}$ & $\begin{array}{l}1.11 \pm 0.11 \\
0.97 \pm 0.12\end{array}$ \\
\hline A. B.2 & $\begin{array}{l}\text { Control } \\
\text { Low sodium }\end{array}$ & $\begin{array}{l}7.41 \\
7.46\end{array}$ & $\begin{array}{l}37 \\
40\end{array}$ & $\begin{array}{l}23.0 \\
27.7\end{array}$ & $\begin{array}{l}24.1-26.6 \\
28.0-30.2\end{array}$ & $\begin{array}{r}101-102 \\
93-102\end{array}$ & $\begin{array}{l}7.58 \pm 0.04 \\
7.58 \pm 0.04\end{array}$ & $\begin{array}{l}53.2 \pm 0.9 \\
44.0 \pm 5.8\end{array}$ & $\begin{array}{l}65.0 \pm 1.1 \\
58.7 \pm 10.8\end{array}$ & $\begin{array}{l}1.05 \pm 1.01 \\
0.95 \pm 0.18\end{array}$ \\
\hline A. $P$. & $\begin{array}{l}\text { Control } \\
\text { Low sodium }\end{array}$ & $\begin{array}{l}7.37 \\
7.39\end{array}$ & $\begin{array}{l}41 \\
43\end{array}$ & $\begin{array}{l}22.7 \\
25.0\end{array}$ & $\begin{array}{l}27.4-30.2 \\
28.7-30.8\end{array}$ & $\begin{array}{l}103-106 \\
102-104\end{array}$ & $\begin{array}{l}7.16 \pm 0.26 \\
7.02 \pm 0.04\end{array}$ & $\begin{array}{l}33.7 \pm 23.7 \\
21.6 \pm 0.9\end{array}$ & $\begin{array}{l}35.8 \pm 33.2 \\
22.1 \pm 2.1\end{array}$ & $\begin{array}{l}0.46 \pm 0.19 \\
0.24 \pm 0.02\end{array}$ \\
\hline L. W. & $\begin{array}{l}\text { Control } \\
\text { Low sodium }\end{array}$ & $\begin{array}{l}7.40 \\
7.38\end{array}$ & $\begin{array}{l}41 \\
39\end{array}$ & $\begin{array}{l}24.5 \\
22.3\end{array}$ & $\begin{array}{l}23.7-27.0 \\
24.8-26.3\end{array}$ & $\begin{array}{r}100-105 \\
99-103\end{array}$ & $\begin{array}{l}7.60 \pm 0.04 \\
7.50 \pm 0.05\end{array}$ & $\begin{array}{l}77.2 \pm 5.6 \\
55.1 \pm 2.3\end{array}$ & $\begin{array}{l}73.9 \pm 3.8 \\
62.6 \pm 8.2\end{array}$ & $\begin{array}{l}2.08 \pm 0.15 \\
1.49 \pm 0.06\end{array}$ \\
\hline L. S. & $\begin{array}{l}\text { Control } \\
\text { Low sodium }\end{array}$ & & & & $\begin{array}{l}28.4-30.6 \\
27.0-29.2\end{array}$ & $\begin{array}{l}97-101 \\
99-100\end{array}$ & $\begin{array}{l}7.54 \pm 0.06 \\
7.26 \pm 0.06\end{array}$ & $\begin{array}{l}74.6 \pm 8.5 \\
33.8 \pm 6.7\end{array}$ & $\begin{array}{l}63.9 \pm 13.3 \\
35.1 \pm 7.5\end{array}$ & $\begin{array}{l}1.55 \pm 0.18 \\
0.70 \pm 0.14\end{array}$ \\
\hline C. G. & $\begin{array}{l}\text { Control } \\
\text { Low sodium }\end{array}$ & $\begin{array}{l}7.41 \\
7.42\end{array}$ & $\begin{array}{l}44 \\
41\end{array}$ & $\begin{array}{l}26.9 \\
25.7\end{array}$ & $\begin{array}{l}26.5-29.6 \\
26.9-30.3\end{array}$ & $\begin{array}{l}98-101 \\
96-101\end{array}$ & $\begin{array}{l}7.63 \pm 0.02 \\
7.43 \pm 0.14\end{array}$ & $\begin{array}{l}54.6 \pm 9.9 \\
33.5 \pm 5.1\end{array}$ & $\begin{array}{l}48.5 \pm 4.2 \\
39.5 \pm 7.2\end{array}$ & $\begin{array}{l}1.09 \pm 0.20 \\
0.67 \pm 0.10\end{array}$ \\
\hline R. C. & $\begin{array}{l}\text { Control } \\
\text { Low sodium }\end{array}$ & $\begin{array}{l}7.40 \\
7.40\end{array}$ & $\begin{array}{l}43 \\
36\end{array}$ & $\begin{array}{l}25.5 \\
21.6\end{array}$ & $\begin{array}{l}25.4-27.4 \\
28.2-29.6\end{array}$ & $\begin{array}{r}104-105 \\
98-105\end{array}$ & $\begin{array}{l}7.57 \pm 0.03 \\
7.59 \pm 0.13\end{array}$ & $\begin{array}{l}35.4 \pm 6.7 \\
46.7 \pm 7.3\end{array}$ & $\begin{array}{l}34.0 \pm 17.0 \\
42.8 \pm 6.5\end{array}$ & $\begin{array}{l}1.06 \pm 0.20 \\
1.40 \pm 0.21\end{array}$ \\
\hline M. S. & $\begin{array}{l}\text { Control } \\
\text { Low sodium }\end{array}$ & $\begin{array}{l}7.38 \\
7.38\end{array}$ & $\begin{array}{l}40 \\
37\end{array}$ & $\begin{array}{l}22.9 \\
21.2\end{array}$ & $\begin{array}{l}24.9-27.2 \\
27.7-30.0\end{array}$ & $\begin{array}{r}103-106 \\
99-101\end{array}$ & $\begin{array}{l}7.69 \pm 0.08 \\
7.70 \pm 0.08\end{array}$ & $\begin{array}{l}57.9 \pm 10.5 \\
52.9 \pm 4.8\end{array}$ & $\begin{array}{l}64.2 \pm 18.3 \\
54.7 \pm 11.3\end{array}$ & $\begin{array}{l}2.07 \pm 0.38 \\
1.89 \pm 0.17\end{array}$ \\
\hline
\end{tabular}

Abbreviations: $\mathrm{pCO}_{2}$, carbon dioxide tension; GF, glomerular filtrate.

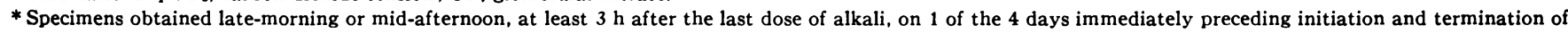
the period of sodium restriction.

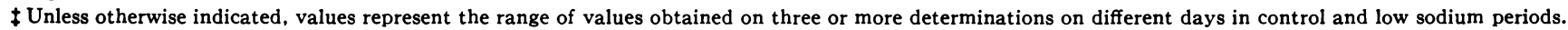
$\$$ Mean \pm SD of values obtained on the final 4 days of the control and low sodium periods.

an abnormality in the renal reabsorption of sodium. Normal subjects made acidotic experimentally might conserve sodium no better than acidotic patients with classic RTA, i.e., acidosis per se might act to impair renal conservation of sodium $(34,35)$. Furthermore, in patients with classic RTA in whom dietary intake of sodium is maintained normal, the occurrence of a reduction in urinary excretion of sodium when acidosis is corrected does not necessarily indicate that the excretion rate of sodium was abnormally high before acidosis was corrected. In normal subjects made acidotic by administration of acid, as in patients with classic RTA made acidotic by discontinuation of alkali therapy, urinary excretion of sodium transiently exceeds dietary intake of sodium and does not become less than the preacidosis excretion rates throughout the period of acidosis despite depletion of body sodium $(34,35)$. Correction of acidosis is attended by a decrease in urinary excretion of sodium and positive sodium balance (34). It remains to be determined to what extent normal subjects and pa- tients with classic RTA differ quantitatively with respect to $(a)$ the cumulative deficit of sodium that occurs during induced acidosis when sodium intake is maintained normal, $(b)$ the cumulative deficit of sodium that occurs when sodium intake is restricted during acidosis, and $(c)$ the cumulative gain of sodium that occurs with correction of acidosis when sodium intake is maintained normal. Although it might be inferred that, in normal subjects and patients with classic RTA who are equally acidotic, the net rate of renal $\mathrm{H}^{+}-\mathrm{Na}^{+}$exchange is less in the patients by an amount approximating their reduction of net acid excretion, it does not necessarily follow that their net rates of reabsorption of sodium or their degree of sodium depletion differ at any level of dietary intake of sodium. Conceivably, in patients with classic RTA, primary disturbances of renal tubular function occur that permit secretion of potassium $\left(\mathrm{K}^{+}-\mathrm{Na}^{+}\right.$ exchange) and/or reabsorption of chloride $(\mathrm{NaCl}$ reabsorption) to enhance reabsorption of sodium sufficiently at any degree of sodium depletion to fully compensate 
for the reduction in sodium reabsorption associated with diminished net acid excretion.

In at least three of the patients studied, the ability to conserve sodium and/or chloride appeared to be wellmaintained during sustained correction of acidosis. But it cannot be inferred that renal conservation of sodium was unimpaired in these patients. Because the magnitude of the error in determination of dietary sodium content was sufficiently great (i.e., $2-3 \mathrm{meq}$ ), it could not be ascertained whether urinary excretion of sodium was appropriately lower than dietary intake of sodium (i.e., by $2-3 \mathrm{meq} / \mathrm{day}$ ), as it characteristically is in sodiumrestricted normal subjects (23-26). Furthermore, with more severe restriction of dietary intake of sodium than was employed in the present study, these patients might have failed to reduce urinary excretion of sodium to rates as low as those reached by normal subjects who are similarly severely restricted. Hence, the possibility cannot be excluded that renal conservation of sodium was impaired in each of the patients in the present study.

A pathophysiological basis for the impairment in renal conservation of sodium demonstrated in some patients with classic RTA is not evident from the data obtained in the present study. On the basis of the values of urinary aldosterone and glomerular filtration rate in these patients (Table IV), neither deficiency of mineralocorticoid nor a large reduction in number of functioning nephrons could be implicated as pathogenetic factors.

The possibility might be considered that the patients were hypervolemic, since before study their intake of sodium had been supernormal, i.e., a normal amount of dietary sodium chloride plus supplemental sodium bicarbonate to maintain correction of acidosis. In hypervolemic normonatremic subjects, renal conservation of sodium might appear to be impaired during restriction of sodium, if only because the negative balance of sodium required to reestablish sodium balance would be greater than that of normovolemic subjects and hence might take longer to achieve. Yet, during an 8-10-day period of sodium restriction in three patients in whom renal conservation of sodium was judged to be impaired, urinary sodium excretion did not decrease progressively during the final 3-4-days of sodium restriction. Accordingly, in these patients it appeared that the limit of the ability of the kidney to reduce urinary excretion of sodium had been reached. Furthermore, hypervolemia would not be a predictable consequence of sustained administration of sodium bicarbonate in just therapeutic amounts in patients with classic RTA maintained on normal amounts of dietary sodium chloride. Acidosis and sodium depletion occur in patients with classic RTA because at normal plasma bicarbonate concentrations the net rate of renal hydrogen ion secretion, and therefore presumably the net rate of $\mathrm{H}^{+}-\mathrm{Na}^{+}$exchange, is subnormal. As a result, the net amount of sodium bicarbonate delivered by the kidney to the plasma and extracellular fluid is subnormal. Continued administration of just therapeutic amounts of sodium bicarbonate would just prevent positive hydrogen ion balance and negative sodium balance from occurring. Although the amount of sodium bicarbonate prescribed for the patients with RTA might have been slightly greater than that just sufficient to maintain correction of acidosis, the amount of sodium represented by such a difference could not have been large and presumably is readily excreted as sodium bicarbonate.

Because bicarbonaturia occurred during sustained correction of acidosis in these patients, it might be argued that the impairment in renal conservation of sodium was a consequence of increased delivery of sodium bicarbonate to the distal nephron. But, the magnitude of the impairment did not correlate positively with the magnitude of bicarbonaturia (Table V). Furthermore, the amount of sodium bicarbonate delivered to the distal nephron is not necessarily supernormal in patients with classic RTA on alkali therapy. At normal plasma bicarbonate concentrations in these patients, bicarbonate reabsorption in the proximal nephron cannot be inferred to be subnormal; bicarbonaturia may reflect incomplete reabsorption of bicarbonate in the distal nephron. The amount of bicarbonate delivered to the distal nephron at normal plasma bicarbonate concentrations is undoubtedly greater than it would be during acidosis, but such increased bicarbonate delivery in patients with classic RTA is generally presumed to augment rather than diminish sodium reabsorption in the distal nephron (5). Moreover, even though the amount of bicarbonate delivered to the distal nephron is greater at normal plasma bicarbonate concentrations than during acidosis, the amount of sodium delivered might be less. Acidosis appears to be attended by a net diminution of sodium reabsorption in the proximal nephron (36-39).

The large amount of potassium bicarbonate ingested by all the patients studied with classic RTA cannot be invoked as the cause of the impairment in renal conservation of sodium evident clearly only in some of these patients. The urinary excretion rates of sodium for the last 3 days of the period of sodium restriction did not correlate with the urinary excretion rates of potassium or bicarbonate for the same period, irrespective of whether the excretion rates of potassium and bicarbonate were expressed as meq $/ 24 \mathrm{~h}$, meq $/ \mathrm{kg}$ of body weight $/ 24$ $\mathrm{h}$, or meq $/ 1.73 \mathrm{~m}^{2} / 24 \mathrm{~h}$.

The impairment of renal conservation of sodium in these patients might reflect a disturbance of renal tubular function related to structural damage of the renal 
medulla associated with infection or deposition of calcium salts. In five of the six patients in whom renal conservation of sodium was impaired, bilateral medullary nephrocalcinosis was evident radiographically and had been present for many years. But, in one patient (A. B.) with marked impairment in renal conservation of sodium and chloride, nephrocalcinosis was not radiographically demonstrable, and there was no evidence of urinary tract infection. Conversely, nephrocalcinosis was present in two patients in whom renal conservation of sodium appeared to be relatively well-maintained. Accordingly, in the group of patients studied, the presence and severity of radiographically-demonstrable nephrocalcinosis does not correlate positively with the presence and severity of the impairment of renal conservation of sodium.

In the patients with Sjogren's syndrome and/or hypergammaglobulinemia, the impairment of renal conservation of sodium and chloride might reflect a disturbance of renal tubular function related to the primary pathological process in the kidney. In such patients, the renal interstitium is diffusely infiltrated with lymphocytes and plasma cells, and immune globulins localize in the cytoplasm and in basement membranes of the renal tubular cells $(40,41)$. In some of these patients, multiple dysfunctions of the tubule occur (14-16).

Whatever the roles of nephrocalcinosis, tubular and interstitial nephritis, and distal bicarbonate delivery in the pathogenesis of impaired renal conservation of sodium in classic RTA, the results of the present study provide no support for the traditional formulation that impaired renal conservation of sodium in classic RTA is exclusively a reversible consequence of the renal acidification defect.

The results of the studies carried out during water diuresis permit localization of the impairment in renal transport of sodium. In L. W., because the concentration of sodium in the urine decreased progressively as urine flow increased (Fig. 6A, solid circles), the abnormally high urinary concentrations of sodium observed during sodium restiction (Fig. 3) could not have reflected solely the limited ability of an impaired distal nephron to reduce the intraluminal concentration of sodium. When reabsorption of water in the distal nephron is suppressed during water diuresis, the urinary concentration of sodium would not be expected to decrease as urine flow increases if that concentration reflected the maximal transepithelial concentration gradient of sodium attainable in the distal nephron (27). The inappropriately high urinary excretion rate of sodium in L. W. might therefore be attributed to an abnormally increased rate of delivery of sodium to the distal nephron, a consequence presumably of impaired reabsorption of sodium in more proximal portions of the neph- ron (i.e., in the nephron proximal to the vasopressinsensitive segments of the distal nephron).

But the results of the study in L. W. do not permit the conclusion that the ability of the distal nephron to reduce the intraluminal concentration of sodium is unimpaired. In this patient and in five additional patients studied, three of whom failed to conserve sodium appropriately by at least one criterion, the minimal urinary concentrations of sodium during water diuresis exceeded the minimal urinary concentrations of sodium observed in sodium-restricted normal subjects undergoing water diuresis (Fig. 6A) (27). That an impairment of sodium transport in the distal nephron could account for such abnormally high urinary concentrations of sodium is indicated by the finding that the urinary excretion rate of sodium increased as urine flow increased (Fig. 6B). If the urinary concentrations of sodium had been abnormally high solely because the ratecapacity for sodium reabsorption in the distal nephron had been saturated by the delivery of abnormally large amounts of sodium from more proximal portions of the nephron, suppression of water reabsorption in the distal nephron would not have been expected to increase the rate of urinary sodium excretion, but only to decrease the concentration of sodium in the urine. Yet, in five patients, the concentration of sodium in the urine remained essentially constant over a broad range of increase in urine flow; in L. W., the urinary sodium concentration decreased but not proportionately to the increase in urine flow. Hence, these findings implicate the vasopressin-sensitive segments of the distal nephron in the impairment of renal conservation of sodium, and suggest that the maximal transepithelial sodium concentration gradient attainable there is abnormally low (27).

The maximal transepithelial sodium concentration gradient in the distal nephron might be abnormally low because the rate of removal of sodium from the lumen is abnormally reduced or because the rate of backflux of sodium into the lumen is abnormally increased. In untreated, acidotic patients with classic RTA, either of these two possibilities can be conceived of as the consequence of an impairment in renal acidification. An abnormally reduced rate of removal of sodium from the lumen might result from an abnormally reduced rate of secretion of hydrogen ion from cell to lumen; an abnormally increased backflux of sodium into the lumen might result from an abnormally increased backflux of hydrogen ion out of the lumen. But, if transport of sodium out of the lumen is abnormally reduced because the rate of hydrogen ion secretion is abnormally reduced, it cannot be expected a priori that correction of systemic acidosis with alkali therapy will normalize it. Raising intraluminal bicarbonate concentration and $\mathrm{pH}$ 
would predictably decrease an abnormally-increased backflux of hydrogen ion from the lumen but it need not increase an abnormally-reduced secretion of hydrogen ion from cell to lumen. The prediction that in patients with classic RTA impaired renal conservation of sodium will be corrected when acidosis is corrected is based upon the assumption that the net rates of renal $\mathrm{H}^{+}-\mathrm{Na}^{+}$ exchange can be normalized by correction of acidosis. Such an assumption might be unwarranted, however, in view of more recently reported evidence, derived from studies of urinary carbon dioxide tension, suggesting that the rate-capacity for hydrogen ion secretion in the distalmost segments of the nephron is abnormally reduced (42). Accordingly, in patients with classic RTA, impaired renal conservation of sodium might be a consequence of impaired renal acidification, but not necessarily a reversible one.

Yet, the impairment in renal conservation of sodium demonstrated in the present patients cannot be conceived of as entirely the consequence of a reduced rate of renal $\mathrm{H}^{+}-\mathrm{Na}^{+}$exchange, since impaired reabsorption of sodium was accompanied by impaired reabsorption of chloride. Conceivably, in classic RTA, impaired renal reabsorption of sodium chloride and impaired renal secretion of hydrogen ion reflect independent renal tubular dysfunctions, perhaps caused by a single abnormality of the renal tubule. The same metabolic or structural abnormality of the renal tubule that precludes establishment of appropriately high intraluminal concentrations of hydrogen ion during acidosis might also preclude establishment of appropriately low intraluminal concentrations of sodium and chloride during salt restriction.

\section{ACKNOWLEDGMENTS}

We thank Edward G. Biglieri, M.D., Director, Clinical Study Center, San Francisco General Hospital, for the determinations of urinary aldosterone.

We gratefully acknowledge the expert technical assistance of Kathleen Nigon, Bernadine Serena, Joan Schweiger, Ann Ince, and Katherine Gully; the secretarial assistance of Gina Harwood and Carolyn Burns; and the collaboration of the nursing staff of the General Clinical Research Center at Moffitt Hospital.

These studies were carried out in the General Clinical Research Center, University of California, San Francisco, with funds provided by the U. S. Public Health Service, Division of Research Resources, RR-00079, and the National Institute of Arthritis, Metabolism, and Digestive Diseases, AM-16764.

\section{REFERENCES}

1. Albright, F., C. H. Burnett, W. Parson, E. C. Reifenstein, Jr., and A. Roos. 1946. Osteomalacia and late rickets: The various etiologies met in the United States with emphasis on that resulting from a specific form of renal acidosis, the therapeutic indications for each etiological sub-group, and the relationship between osteomalacia and Milkman's syndrome. Medicine. 25: 399479.
2. Pines, K. L., and G. H. Mudge. 1951. Renal tubular acidosis with osteomalacia: Report of three cases. Am. J. Med. 11: 302-311.

3. Mahler, R. F., and S. W. Stanbury. 1956. Potassiumlosing renal disease. Renal and metabolic observations on a patient sustaining renal wastage of potassium. Q. $J$. Med. 25: 21-52. (Plate 4).

4. Gill, J. R., Jr., N. H. Bell, and F. C. Bartter. 1961. Correction of renal sodium loss and secondary aldosteronism in renal tubular acidosis with bicarbonate loading. Clin. Res. 9: 201. (Abstr.)

5. Gill, J. R., Jr., N. H. Bell, and F. C. Bartter. 1967. Impaired conservation of sodium and potassium in renal acidosis and its correction by buffer anions. Clin. Sci. (Oxf.). 33: 577-592.

6. Sebastian, A., E. McSherry, and R. C. Morris, Jr. 1971. On the mechanism of renal potassium wasting in renal tubular acidosis associated with the Fanconi syndrome (Type 2 RTA). J. Clin. Invest. 50: 231-243.

7. Sebastian, A., E. McSherry, and R. C. Morris, Jr. 1971. Renal potassium wasting in renal tubular acidosis (RTA). Its occurrence in types 1 and 2 RTA despite sustained correction of systemic acidosis. J. Clin. Invest. 50: 667-678.

8. McSherry, E., A. Sebastian, and R. C. Morris, Jr. 1972. Renal tubular acidosis (RTA) in infants: The several kinds, including bicarbonate-wasting, classic renal tubular acidosis. J. Clin. Invest. 51: 499-514.

9. Reynolds, T. B. 1972. Renal tubular disorders. In Disorders of Fluid and Electrolyte Metabolism. M. H. Maxwell and C. R. Kleeman, editors. Second edition, McGraw-Hill Book Co. New York. Chapter 21. 811-833.

10. Smith, L. H., Jr. 1960. Renal tubular acidosis. In The Metabolic Basis of Inherited Disease. J. B. Stanbury, J. Wyngaarden, and D. S. Fredrickson, editors. McGraw-Hill Book Co., New York. Chapter 39. 1256-1273.

11. Rodriguez-Soriano, J., and C. M. Edelmann, Jr. 1969. Renal tubular acidosis. Ann. Rev. Med. 20: 363-382.

12. Windhager, E. E. 1969. Kidney, water, and electrolytes. Ann. Rev. Physiol. 31: 117-172.

13. Seldin, D. W., and J. D. Wilson. 1966. Renal tubular acidosis. In The Metabolic Basis of Inherited Disease. J. B. Stanbury, J. Wyngaarden, and D. S. Fredrickson, editors. McGraw-Hill Book Co., New York. 2nd edition. Chapter 54. 1230-1246.

14. Shearn, M. A., and W. H. Tu. 1965. Nephrogenic diabetes insipidus and other defects of renal tubular function in Sjogren's syndrome. Am. J. Med. 39: 312-318.

15. Morris, R. C., Jr., A. Sebastian, E. Morris, and I. Ueki. 1968. Hypergammaglobulinemic renal tubular acidosis: a spectrum of physiological disturbances. J. Clin. Invest. 47: 70a-71a. (Abstr.)

16. Walker, B. R., F. Alexander, and Ph.J. Tannenbaum. 1971. Fanconi syndrome with renal tubular acidosis and light chain proteinuria. Nephron. 8: 103-107.

17. Wrong, O., and H. E. F. Davies. 1959. The excretion of acid in renal disease. Q. J. Med. 28: 259-313. (Plates 19 and 20 ).

18. Morris, R. C., Jr., and H. H. Fudenberg. 1967. Impaired renal acidification in patients with hypergammaglobulinemia. Medicine. 46: 57-69.

19. Peonides, A., B. Levin, and W. F. Young. 1965. The renal excretion of $\mathrm{H}^{+}$ion in infants and children. Arch. Dis. Child. 40: 33-39.

20. Morris, R. C., Jr., C. F. Piel, and E. Audioun. 1965. Renal tubular acidosis: effects of sodium phosphate and 
sulfate on renal acidification in two patients with renal tubular acidosis. Pediatrics. 36: 899-904.

21. Morris, R. C., Jr. 1968. An experimental renal acidification defect in patients with hereditary fructose intolerance. II. Its distinction from classic renal tubular acidosis: its resemblance to the renal acidification defect associated with the Fanconi syndrome of children with cystinosis. J. Clin. Invest. 47: 1648-1663.

22. Watt, B. K., and A. L. Merrill. 1963. In Composition of Foods. Raw. Processed. Prepared. Consumer and Food Economics Research Division Agricultural Research Service, United States Department of Agriculture, Washington, D. C. (Revised).

23. Crabbé, J., E. J. Ross, and G. W. Thorn. 1958. The significance of the secretion of aldosterone during dietary sodium deprivation in normal subjects. J. Clin. Endocrinol. Metab. 18 : 1159-1177.

24. Luetscher, J. A., Jr., and B. J. Axelrod. 1954. Increased aldosterone output during sodium deprivation in normal man. Proc. Soc. Exp. Biol. Med. 87: 650-653.

25. Leaf, A., and W. T. Couter. 1949. Evidence that renal sodium excretion by normal human subjects is regulated by adrenal cortical activity. J. Clin. Invest. 28: 1067-1081.

26. Brown, J. J., D. L. Davies, A. F. Lever, and J. I. S. Robertson. 1964. Influence of sodium deprivation and loading on the plasma-renin in man. J. Physiol. 173: 408-419.

27. Coleman, A. J., M. Arias, N. W. Carter, F. C. Rector, Jr., and D. W. Seldin. 1966. The mechanism of salt wastage in chronic renal disease. J. Clin. Invest. 45: 1116-1125.

28. Lightwood, R., W. W. Payne, and J. A. Black. 1953. Infantile renal acidosis. Pediatrics. 12: 628-644.

29. Smith, L. H., Jr., and G. E. Schreiner. 1954. Studies on renal hyperchloremic acidosis. J. Lab. Clin. Med. 43: 347-358.

30. Reynolds, T. B. 1958. Observations on the pathogenesis of renal tubular acidosis. Am. J. Med. 25: 503-515.

31. Soriano, J. R., H. Boichis, and C. M. Edelmann, Jr. 1967. Bicarbonate reabsorption and hydrogen ion ex- cretion in children with renal tubular acidosis. J. Pediatr. $71: 802-813$.

32. Morris, R. C., Jr. 1969. Renal tubular acidosis: Mechanism, classification and implications. N. Engl. J. Med. 281: 1405-1413.

33. Stanbury, S. W. 1961. Some factors concerned in the regulation of potassium excretion by the normal and diseased kidney in man. Proc. 1st. Int. Congr. Nephrol. $1: 40-51$.

34. Sartorious, O. W., J. C. Roemmelt, and R. F. Pitts. 1949. The renal regulation of acid-base balance in man: IV. The nature of the renal compensations in ammonium chloride acidosis. J. Clin. Invest. 28: 423-439.

35. Wood, F. J. Y. 1955. Ammanium chloride acidosis. Clin. Sci. 14 : 81-89.

36. Kokko, J. P., F. C. Rector, and D. W. Seldin. 1970. Mechanism of salt and water reabsorption in proximal convoluted tubule (PCT). Amer. Soc. Nephrol. Abstract, p. 42.

37. Stein, J. C., F. C. Rector, Jr., and D. W. Seldin. 1968. The effect of acute metabolic acidosis on proximal tubular sodium reabsorption in the rat. J. Clin. Invest. 47: 93a. (Abstr.)

38. Ullrich, K. J., H. W. Radtke, and G. Rumrich. 1971. The role of bicarbonate and ather buffers on isotonic fluid absorption in the proximal convolution of the rat kidney. Arch. Gest. Physiol. 330: 149-161.

39. Safirstein, R., V. P. Glassman, and V. A. DiScala. 1973. Effects of an $\mathrm{NH}_{4} \mathrm{Cl}$-induced metabolic acidosis on salt and water reabsorption in dog kidney. Am. J. Physiol. 225 : 805-809.

40. Pasternack, A., and E. Linder. 1970. Renal tubular acidosis: an immunopathological study on four patients. Clin. Exp. Immunol. 7 : 115-123.

41. Shoji, R., T. Furuyama, S. Onodera, H. Saito, H. Ito, and Y. Sasaki. 1970. Sjogren's syndrome and renal tubular acidosis. Am. J. Med. 48: 456-463.

42. Halperin, M. L., M. B. Goldstein, A. Haig, M. D. Johnson, and B. J. Stinebaugh. 1974. Studies on the pathogenesis of type I (distal) renal tubular acidosis as revealed by the urinary $\mathrm{PCO}_{2}$ tensions. J. Clin. Invest. 53 : 669-677. 